\title{
A Autonomia da Vontade Contratual para a solução de conflitos contratuais no ordenamento jurídico brasileiro: considerações após a recepção no ordenamento brasileiro da Convenção das Nações Unidas para os Contratos de Compra e Venda Internacional de Mercadorias
}

\author{
The Autonomy of Contractual Will for the solution of contractual conflicts in the Brazilian \\ legal system: considerations after the reception in the Brazilian legal system of the United \\ Nations Convention on Contracts for the International Sale of Goods
}

Alvaro Augusto Santos Caldas Gouveia*

Eugênia Cristina Nilsen Ribeiro Barza* ${ }^{*}$

\section{REFERÊNCIA}

GOUVEIA, Alvaro Augusto Santos Caldas; BARZA, Eugênia Cristina Nilsen Ribeiro. A Autonomia da Vontade como solução de conflitos contratuais no ordenamento jurídico brasileiro: considerações após a recepção no ordenamento brasileiro da Convenção das Nações Unidas para os Contratos de Compra e Venda Internacional de Mercadorias. Revista da Faculdade de Direito da UFRGS, Porto Alegre, n. 42, p. 63-95, abr. 2020. DOI: <https://doi.org/10.22456/0104-6594.84561>.

\begin{abstract}
RESUMO
Trata-se de tema relativo ao Direito Internacional Privado e Direito do Comércio Internacional, cujo objetivo principal é analisar os efeitos da incorporação da CISG no ordenamento jurídico brasileiro, considerando a aplicação do princípio da autonomia da vontade em contratos internacionais de comércio. Fez-se um estudo exploratório, com método dedutivo, a partir de dados secundários sobre solução de conflitos de lei no espaço no comércio internacional, tendo como pergunta principal avaliar se houve uma ampliação da autonomia da vontade contratual no ordenamento jurídico brasileiro após a recepção da CISG. Partindo do contexto das transformações no comércio internacional Pós-Segunda Guerra Mundial, no qual surgem efetivamente possibilidades trazidas pela unificação, uniformização e harmonização jurídica, avaliam-se elementos relevantes da contribuição do texto da CISG para a solução de Conflitos de Lei no Espaço. Comparando dispositivos da CISG com outros, do Código Civil Brasileiro de 1916 e da Lei $n^{\circ}$ 9.307/1966, observam-se as repercussões do princípio da autonomia da vontade em contratos internacionais de comércio.
\end{abstract}

\section{PALAVRAS-CHAVE}

Contratos de compra e venda internacional de mercadorias. Autonomia da vontade. Solução de conflitos.

\begin{abstract}
This is a topic related to Private International Law and International Trade Law, whose main objective is to analyze the effects of the incorporation of the CISG into the Brazilian legal system, considering the application of the principle of autonomy of the will in international trade contracts. An exploratory study was carried out, using a deductive method, based on secondary data on the solution of conflicts of law in the international trade space. The main question was whether there was an increase in the autonomy of the contractual will in the Brazilian legal system after the reception of the CISG. From the context of the post-World War II international trade transformations, in which the possibilities brought about by unification, uniformity and legal harmonization emerge, relevant elements of the contribution of the CISG text to the solution of Conflicts of Law
\end{abstract}

\footnotetext{
** Mestre em Direito Público e Doutorando em Direito Internacional Privado - UFPE. Pesquisador participante do Grupo de Pesquisa "Integração regional, globalização e direito internacional", na linha de pesquisa "Direito da integração regional e processos de integração da América Latina" da UFPE.

*** Professora Assistente, Doutora em Direito, Faculdade de Direito do Recife-Centro de Ciências Jurídicas, Programa de Pós-graduação em Direito (PPGD) Universidade Federal de Pernambuco (UFPE) e líder do grupo de pesquisa “Integração Regional, Globalização e Direito Internacional”.
} 
are evaluated. Comparing CISG articles with others, the Brazilian Civil Code of 1916 and Law No. 9,307/1966, the repercussions of the principle of autonomy of the will in international trade contracts are observed.

\section{KEYWORDS}

Contracts for the international sale of goods. Autonomy of the will. Conflict resolution.

\section{SUMÁRIO}

1. Introdução. 2. Questões gerais sobre comércio internacional na sociedade internacional após a Segunda Guerra Mundial (1939-1945). 2.1 Integração e Pluralismo Cultural. 2.2 Unificação, Uniformização e Harmonização jurídica. 3. Sobre a Convenção das Nações Unidas para os Contratos de Compra e Venda Internacional de Mercadorias (CISG). 3.1 Breve histórico. 3.2 Interpretação de seu objeto. 3.3 Papel da Autonomia da Vontade em seu texto. 4 Autonomia da Vontade Contratual no ordenamento jurídico brasileiro. 4.1 Sob a égide do Código Civil de 1916. 4.2 O advento da Lei n 9.307/1996. 4.3 À luz da CISG. 5. Conclusão. Referências. Dados da publicação. 


\section{INTRODUÇÃO}

O comércio internacional é fenômeno milenar e sua origem se deu em virtude da impossibilidade dos povos de produzirem todos os bens e serviços que necessitam para viver. Dessa forma, surgiu uma demanda por trocas para obtenção daquilo que se necessitava. Com o aumento dos montantes envolvidos e da frequência dessas trocas internacionais ao longo da história - alcançando seu ápice após a Segunda Grande Guerra em um fenômeno comumente denominado Globalização - adveio o problema relativo à definição da lei aplicável sobre tais contratos, uma vez que os ordenamentos jurídicos dos Estados nacionais são distintos em razão dos valores culturais predominantes em suas sociedades.

Em face desse pluralismo cultural, algumas formas de solução de conflitos normativos (antinomias) foram aventadas, tais como a unificação, a uniformização e a harmonização dos distintos ordenamentos jurídicos. Dentre essas diversas tentativas de solução, no que diz respeito especificamente aos contratos internacionais de compra e venda de mercadorias, foi criada a Convenção das Nações Unidas sobre Contratos de Compra e Venda Internacional de Mercadorias.

A Convenção das Nações Unidas sobre Contratos de Compra e Venda Internacional de Mercadorias, em língua inglesa denominada United Nations Convention on Contracts for the International Sales of Goods (doravante chamada apenas de CISG), foi celebrada em 11 de abril de 1980 por meio dos trabalhos da Comissão das Nações Unidas sobre Direito Comercial Internacional (em inglês United Nations Comission on International Trade Law ou, simplesmente, UNCITRAL), e é tida como um dos grandes diplomas internacionais sobre o Direito Internacional Privado.

Seu grande objetivo é a facilitação do comércio internacional por meio da diminuição dos custos de transação resultantes da incerteza da lei aplicável sobre os contratos internacionais, a fim de proporcionar um maior fluxo de contratos internacionais de venda de mercadorias.

Nesse contexto, em caso de omissão contratual, dentre as formas utilizadas pela CISG para a diminuição dos custos de transação dos contratos de compra e venda internacional de mercadorias está a consagração convencional da autonomia da vontade dos contratantes como critério para solução de possíveis controvérsias oriundas desses contratos, com a utilização de usos e costumes ou práticas internacionais a que tiverem consentido (artigo 9). 
Por meio de uma revisão doutrinária da matéria relativa à CISG e à autonomia da vontade como critério para solução de controvérsias contratuais internacionais, por meio do método dedutivo, tenciona-se responder à seguinte questão: houve uma ampliação da autonomia da vontade contratual no ordenamento jurídico brasileiro após a recepção da CISG pelo Brasil?

\section{QUESTÕES GERAIS SOBRE COMÉRCIO INTERNACIONAL NA SOCIEDADE INTERNACIONAL APÓS A SEGUNDA GUERRA MUNDIAL (1939-1945)}

Neste primeiro capítulo tenciona-se demonstrar a magnificação da complexidade das relações do comércio internacional oriunda dos diversos prismas culturais que surgiram do aumento do número de atores internacionais, especialmente os Estados nacionais, e as estratégias jurídicas elaboradas para ultrapassar tal complexidade e estabelecer relações comerciais mais constantes e estáveis.

\subsection{Integração e Pluralismo Cultural}

Após a Segunda Guerra Mundial (1939-1945) e a Guerra Fria (1945-1989), a sociedade internacional passa a enfrentar desafios muito grandes em seu cotidiano, para os quais a criação de uma normatividade abrangente que os tutele é medida essencial para uma harmônica convivência entre os componentes dessa sociedade. Como um dos critérios a se considerar para a elaboração de tal conjunto normativo, há que se questionar acerca das diferenças culturais que marcam a contemporaneidade.

Com o objetivo de propor uma solução para um desejo de integração limitado pelas diferenças culturais, Erik Jayme propôs a teoria do Diálogo das fontes ${ }^{1}$. Tal teoria é calcada na ideia de que nenhuma fonte pode ser aprioristicamente descartada para o alcance da solução de um conflito de leis em Direito Internacional Privado (DIPr), assim criando um novo modelo baseado na harmonia entre fontes de origens distintas. Seu objetivo era equilibrar duas ideias opostas: uma intenção dos Estados em se aproximar economicamente

1 Esta teoria foi apresentada por Jayme no curso que ele ministrou na Academia de Direito Internacional de Haia, no ano de 1995. Vide: JAYME, Erik. Identité culturelle et intégration: le droit international privé postmoderne. Recueil des Cours, The Hague, v. 251, p. 9-267, 1996. 
(resultando na criação de leis uniformes) e de outro as diferentes identidades culturais que fragmentam o direito no mundo (e que geram grande número de conflitos de leis) ${ }^{2}$.

Dessa forma, observando-se a crescente internacionalização de relações pessoais e patrimoniais, seria imprescindível uma elasticidade do DIPr para a proteção da identidade cultural dos povos, fazendo-se necessário repensar a estrutura tradicional desse ramo do Direito e criar uma abertura a novos valores.

Assim, Jayme afirma o desenvolvimento do DIPr é influenciado por quatro fatores que caracterizam a cultura pós-moderna ${ }^{3}$, quais sejam: o pluralismo, a comunicação, a narração e o retorno aos sentimentos ${ }^{4}$. Nesse sentido, importa ressaltar que Jayme faz exemplo de cada um desses fatores da cultura pós-moderna e, no que diz respeito ao pluralismo, indica a autonomia da vontade - que se estende desde o direito de família até às obrigações - como forma de consubstanciação do direito à diferença ${ }^{5}$.

Nesse sentido, a teoria do Diálogo das Fontes propõe a simultânea utilização de fontes diversas para a solução de um conflito de leis a fim de garantir a identidade cultural do indivíduo, tendo os princípios protetores de direitos fundamentais como elementos norteadores da escolha do Direito aplicável e, portanto, superar a tradicional estrutura das regras de conexão que prevê exclusões apriorísticas de normas para o deslinde do conflito de leis ${ }^{6}$.

2 ARAUJO, Nadia de; SPITZ, Lidia; TEIXEIRA, Bruno Barreto de Azevedo. Diálogo das fontes: interações entre a lei doméstica e a CISG. In: VENOSA, Sílvio de Salvo; GAGLIARDI, Rafael Villar; TERASHIMA, Eduardo Ono (orgs.). A Convenção de Viena sobre Contratos de Compra e Venda Internacional de Mercadorias: desafios e perspectivas. São Paulo: Atlas, 2015, p. 591.

3 Conforme Terry Shinn (Desencantamento da modernidade e da pós-modernidade: diferenciação, fragmentação e a matriz de entrelaçamento. Sci. stud., São Paulo, v. 6, n. 1, p. 43-81, Mar. 2008 . Disponível em:

$<$ http://www.scielo.br/scielo.php?script=sci_arttext\&pid=S1678-31662008000100003\&lng=en\&nrm=iso $>$. Acesso em: 18 jul. 2019): tal pós-modernidade é menos consensual e homogênea do que a análise da realidade proposta pela modernidade. A modernidade anunciara um desencantamento do mundo, ou seja, o fim da crença na salvação e no espírito de pertinência e coesão da humanidade baseada em fatores sobrenaturais. $\mathrm{Na}$ modernidade, dentre outras características, há a presença de um determinismo marcante, ou seja, "as trajetórias sociais, intelectuais, civis e mesmo pessoais do indivíduo são também a consequência de forças deterministas que fecham certas vias enquanto abrem outras. A modernidade é, assim, um sistema marcado pela causalidade e por fronteiras". Já a pós-modernidade tem sua gênese na segunda metade do século XX, com suas novas formas de cognição (meios remotos de conhecimento) e tecnologia (informática, internet), enfatizando-se a indeterminação e a contingência das coisas, pessoas e relações.

4 JAYME, Erik. Identité culturelle et intégration: le droit international privé postmoderne. Recueil des Cours, The Hague, v. 251, p. 36, in verbis: "La culture postmoderne est caractérisée essentiellement par quatre phénomènes: le pluralism, la communication, la narration et le retour des sentiments. Ces traits typiques postmodernes sont en train d'influencer le développment du droit y compris les solutions de conflits de lois et de juridictions".

5 Ibidem, p. 256.

6 ARAUJO, Nadia de; SPITZ, Lidia; TEIXEIRA, Bruno Barreto de Azevedo. Diálogo das fontes: interações entre a lei doméstica e a CISG. In: VENOSA, Sílvio de Salvo; GAGLIARDI, Rafael Villar; TERASHIMA, Eduardo Ono (orgs.). A Convenção de Viena sobre Contratos de Compra e Venda Internacional de Mercadorias: desafios e perspectivas. São Paulo: Atlas, 2015, p. 592. 
Entretanto, na tentativa de resolver os conflitos de leis no espaço, outras possíveis soluções já haviam sido antes elaboradas, com se verá a seguir.

\subsection{Unificação, Uniformização e Harmonização jurídica}

Como a sociedade internacional a partir do último quartel do Século XX caracteriza-se como aquela na qual barreiras são paulatinamente quebradas e, assim, o mundo se torna plano $^{7}$, pode-se observar a presença uma liberdade não antes vista nos âmbitos: econômico, comercial, social e jurídico. A tal contexto do pós-Segunda Grande Guerra pode-se denominar Globalização.

A Globalização é um processo político que, consoante Ocampo, “tende à integração dos Estados, que nasceu a partir de um fato cultural (as inovações tecnológicas e a revolução das comunicações) e que tem consequências econômicas, sociais, culturais e políticas e seu corolário no universo jurídico"8.

Apesar de possuir origens remotas (Roma, navegações da Idade Média), é após a Revolução Industrial (Séculos XVIII e XIX) que tal processo se fortalece com as inovações tecnológicas em escala comercial que fizeram o mundo mais ágil e com dias mais longos (trens, automóveis, telefone, lâmpada elétrica, etc) a fim de aumentar a produtividade. Dessa forma, apesar do hiato entre guerras no processo globalizante, após a Segunda Grande Guerra (1939-1945) houve um novo ciclo de crescimento do intercâmbio comercial internacional que, atualmente, é tecnologicamente calcado em um meio ainda mais rápido de comunicação (internet) e faz com que a comunicação se faça não mais em âmbito nacional, mas sim em âmbito global ${ }^{9}$.

Nesse sentido, o fenômeno globalizante demanda a solução de conflitos normativos entre ordenamentos estatais da forma menos onerosa para os agentes econômicos em um mercado internacional, ou seja, com os menores custos de transação possíveis ${ }^{10}$, a fim de que

7 FRIEDMAN, Thomas L. The World is Flat: a brief history of the twenty-first century. $3^{\text {rd }}$ ed., further updated and expanded. New York: Picador/Farrar, Straus and Giroux, 2007, p. 5-8.

8 OCAMPO, Raúl Granillo. Direito Internacional Público da Integração. Rio de Janeiro: Elsevier, 2009, p. 7.

9 Ibidem, p. 8-10.

10 Custos de transação são todos aqueles que devem ser levados em conta para a celebração de acordos no mercado. Assim, como escolhas têm que ser feitas diariamente, os agentes econômicos sopesam custos e benefícios de cada possibilidade, o que a economia denomina uma conduta "racional maximizadora". Tais escolhas podem estar sujeitas a uma alteração que não leve em conta somente os fatores internos do agente econômico, mas também os incentivos que se apresentem no momento da decisão, ou seja, os agentes econômicos podem ser levados a tomar outra decisão porque respondem a incentivos. Uma das formas mais utilizadas de incentivos (positivos e negativos) é o Direito. Vide: GICO JR, Ivo T. Metodologia e Epistemologia da Análise Econômica do Direito. Economic Analysis of Law Review, v. 1, n. 1, p. 22, jan-jun, 2010. Disponível em: <https://portalrevistas.ucb.br/index.php/EALR/article/view/1460>. Acesso em: 01 mar. 2017. 
haja o maior retorno para esses agentes. Assim, no âmbito jurídico, a existência de complexas soluções normativas estatais para a resolução do conflito de leis no espaço faz com que as transações comerciais se tornem mais custosas, haja vista que os custos de transação são aumentados em face da inacessibilidade do conteúdo das normas de solução desses conflitos por agentes econômicos leigos, o que se torna mais dramático em face de uma crescente demanda por transações internacionais de comércio. Portanto, quanto mais incerteza na forma de solução de conflitos de leis houver, maiores são os custos de transação e menos incentivados se sentem os agentes econômicos.

A fim de diminuir os custos de transação no âmbito do comércio internacional ${ }^{11}$ e gerar um maior fluxo de contratos internacionais, algumas estratégias jurídicas foram tomadas, tais como a Unificação, a Harmonização e a Uniformização das normas que regem esse comércio.

A Unificação é estratégia que tenciona criar uma regulamentação detalhada e idêntica em todos os seus aspectos, vinculando todos os membros de um conjunto. Entretanto, no campo do comércio internacional, ao contrário do direito interno, a aplicação de tal estratégia mostra-se bastante problemática porque envolveria não somente uma mudança em todos os sistemas jurídicos estatais, mas também seria apenas fugaz, pois as interpretações da norma unificada pelas jurisdições internas (com base nos próprios Direitos estatais internos) seria efetivamente distinta (pois baseada em valores potencialmente distintos), o que tornaria a unificação das normas sobre comércio internacional de improvável implementação ${ }^{12}$.

Por outro lado, a Harmonização propõe uma aproximação de legislações distintas, para âmbitos jurídicos determinados ${ }^{13}$, com o estabelecimento de critérios de interpretação amplos e obriga as partes envolvidas a complementar esse arcabouço normativo comum por meio da

11 Tais como os custos de negociação e fixação de contrapartidas e salvaguardas contratuais e os custos de monitoramento, renegociação e adaptação dos termos contratuais às novas circunstâncias ou, até mesmo, o custo da análise legal dos contratos internacionais com dispositivos da ordem judicial dos Estados envolvidos (legal due diligence). Para mais, vide: SOUZA JR., Lauro Gama. A Convenção de Viena sobre compra e venda internacional de mercadorias. In: BAPTISTA, Luiz Olavo; MAZZUOLI, Valerio de Oliveira (orgs.). Direito Internacional: Direito do Comércio Internacional, v. 5. São Paulo: RT, 2012, p. 721 e CASADO FILHO, Napoleão. Breve introdução sobre a CISG e sua aplicabilidade no Brasil. In: VENOSA, Sílvio de Salvo; GAGLIARDI, Rafael Villar; TERASHIMA, Eduardo Ono (orgs.). A Convenção de Viena sobre Contratos de Compra e Venda Internacional de Mercadorias: desafios e perspectivas. São Paulo: Atlas, 2015, p. 12.

12 Para Pignatta, um exemplo de Unificação seria o Direito Associativo francês, que é regido pela Lei de $1^{\circ} \mathrm{de}$ Julho de 1901, mas que nas regiões da Alsácia e Mosela, aplicam-se as disposições do Código Civil local (Alsácia-Mosela). Para mais, vide: PIGNATTA, Francisco Augusto. A uniformização das regras do contrato de compra e venda internacional de mercadorias: suas vantagens, seus desafios. In: SCHWENZER, Ingeborg; PEREIRA, Cesar A. Guimarães; TRIPODI, Leandro (coords.). A CISG e o Brasil: Convenção das Nações Unidas para os Contratos de Compra e Venda Internacional de Mercadorias. São Paulo: Martial Pons, 2015, p. 39-40.

13 FRADERA, Vera Jacob de. O caráter internacional da CISG. In: VENOSA, Sílvio de Salvo; GAGLIARDI, Rafael Villar; TERASHIMA, Eduardo Ono (orgs.). A Convenção de Viena sobre Contratos de Compra e Venda Internacional de Mercadorias: desafios e perspectivas. São Paulo: Atlas, 2015, p. 205. 
criação de normas que melhor se encaixem com os valores próprios de cada sociedade. Tal tipo de estratégia é de aplicação mais ampla, tal como em associações de Estados (por razões geográficas - União Europeia; ou políticas - Organização do Tratado do Atlântico Norte). No que tange às regras do comércio internacional, sua aplicação se mostra limitada um bloco de Estados determinado, sendo de difícil aplicação em âmbito global, pois demandaria a adoção de leis semelhantes e, inclusive, de um órgão supranacional que garantisse sua aplicação (ex: Tribunal de Justiça da União Europeia) $)^{14}$.

A Uniformização normativa consiste em conferir mesma forma a objetos jurídicos determinados (ex: compra e venda internacional de mercadorias), bem como que as partes envolvidas se aproximem quanto a esse aspecto regulado, ou seja, que haja a elaboração de um instrumento normativo único, seja de hard law (convenção internacional) ou de soft law ${ }^{15}$.

Observe-se que em caso de Uniformização via soft law, Pignatta afirma que ao lado da ação dos Estados vinculados (aprovação do texto), há também a necessidade de ação das partes e do juiz, por meio de uma aplicação uniforme da norma aprovada. Assim, a aplicação de uma norma uniforme demanda o preenchimento das seguintes etapas: conhecimento, raciocínio e implementação. Na primeira fase, o julgador deve conhecer profundamente o texto da norma uniforme (seus objetivos, princípios norteadores); na segunda fase, não somente o conhecimento do texto é essencial, mas também sua intepretação deve ser uniforme; por fim, a fim de evitar interpretações colidentes, deve-se considerar a aplicação do texto da norma internacional de forma independente em relação a outros sistemas jurídicos, ou seja, como um sistema completo e autossuficiente ${ }^{16}$.

14 No caso da União Europeia a harmonização se faz por meio da edição de Diretivas que, emanadas pelo Conselho da União Europeia (e, em alguns casos em conjunto com o Parlamento Europeu), objetivam a adaptação das normas internas dos membros desse bloco às linhas mestras dispostas nas Diretivas, todavia lhes conferindo a liberdade na inserção de seu conteúdo da forma como escolhida pelo Estado Membro, sem necessariamente ter um texto idêntico. Vide: BORGES, José Souto Maior. Curso de Direito Comunitário. 2. ed. São Paulo: Saraiva, 2009, p. 625-631.

15 Conforme Soares, soft law e hard law se distinguem em razão do: "fator tempo (a hard law seria um produto acabado, ao final de uma evolução geracional ao longo do tempo, portanto, a norma terminada em sua inteireza, e soft seria um vir a ser, um ato em potência, um ato de vontade dos Estados, que aspira a tornar-se uma norma), quanto o fator finalidade (na hard law, os Estados estabelecem obrigações jurídicas fortes, para serem efetivamente cumpridas, e na soft law existem normas jurídicas, mas seu cumprimento é meramente recomendado aos Estados, que podem, inclusive, não cumpri-las, sem que haja sanções aplicáveis aos inadimplentes)". Vide: SOARES, Guido Fernando Silva. Curso de Direito Internacional Público. v. 1. 2. ed. São Paulo: Saraiva, 2004, p. 136-140. Observe-se que apesar de Soares falar que a soft law não comporta sanções, isso só é verdade no âmbito estritamente jurídico, já que nos âmbitos social e econômico internacionais, a consequência de não cumprimento de uma norma de soft law (declarações, recomendações, leis-modelo, etc) é o afastamento ou até mesmo a exclusão no inadimplente do aspecto internacional tutelado pela norma de soft law internacional, tal como no caso em tela, o comércio internacional.

16 PIGNATTA, Francisco Augusto. A uniformização das regras do contrato de compra e venda internacional de mercadorias: suas vantagens, seus desafios. In: SCHWENZER, Ingeborg; PEREIRA, Cesar A. Guimarães; TRIPODI, Leandro (coords.). A CISG e o Brasil: Convenção das Nações Unidas para os Contratos de Compra e 
Assim, no próximo capítulo será abordada a CISG como uma estratégia de uniformização das regras regentes do comércio internacional a fim de diminuir a os custos de transação e estimular o desenvolvimento do comércio internacional.

\section{SOBRE A CONVENÇÃO DAS NAÇÕES UNIDAS PARA OS CONTRATOS DE COMPRA E VENDA INTERNACIONAL DE MERCADORIAS}

No presente capítulo será feita uma apresentação da CISG, considerando-se o contexto de sua criação, a razão de sua gênese e a demonstração de seu objeto, qual seja, a tutela internacionalmente harmônica da compra e venda internacional de mercadorias, culminando com uma explanação da autonomia conferida às partes contratantes no bojo de seu texto para a tutela do próprio contrato.

\subsection{Breve histórico}

A CISG é resultado da maturação de um processo de uniformização do Direito do Comércio Internacional. Anteriormente à sua criação, podem-se citar três ocasiões em que projetos de direito uniforme para contratos de compra e venda internacional de mercadorias foram elaboradas: a primeira foi o encaminhamento de dois projetos de leis uniformes à Liga das Nações na década de 1930, mas que em face do advento da Segunda Grande Guerra não prosperou; a segunda ocasião iniciou-se com a iniciativa holandesa de patrocinar uma conferência diplomática para discutir diretrizes sobre compra e venda internacional de mercadorias, o que gerou um novo anteprojeto que foi publicado em $1956^{17}$; por fim, a terceira ocasião teve lugar em 1964, como resultado do trabalho de 30 anos do Instituto Internacional para a Unificação do Direito Privado (UNIDROIT), e duas convenções foram elaboradas e assinadas em Haia no ano de 1964, quais sejam: a Lei Uniforme de Compra e Venda Internacional o Comércio Internacional de Mercadorias e a Lei Uniforme para a Formação de Contratos para o Comércio Internacional de Mercadorias. Todavia, essas convenções só foram ratificadas por oito Estados ${ }^{18}$.

Venda Internacional de Mercadorias. São Paulo: Martial Pons, 2015, p. 49-54.

17 TRIPODI, Leandro. A Convenção de Viena de 1980: esboço de sua gênese histórica e estrutura normativa. In: VENOSA, Sílvio de Salvo; GAGLIARDI, Rafael Villar; TERASHIMA, Eduardo Ono (orgs.). A Convenção de Viena sobre Contratos de Compra e Venda Internacional de Mercadorias: desafios e perspectivas. São Paulo: Atlas, 2015, p. 4-5.

18 ROWE, Michael. Convenção das Nações Unidas sobre lei do comércio internacional. In: BAPTISTA, Luiz Olavo; MAZZUOLI, Valerio de Oliveira (orgs.). Direito Internacional: Direito do Comércio Internacional, v. 5. São Paulo: RT, 2012, p. 876. 
Essa baixa aceitação internacional das Leis Uniformes de Haia se deu em razão de diversos fatores, tal como a complexidade do critério para sua aplicação previsto em seu texto: a) partes situadas em Estados diferentes e; b) condições do contrato de compra e venda (que os bens objetos da compra e venda estivessem em trânsito ao tempo do contrato ou que posteriormente fossem transportados internacionalmente; ou que os atos de oferta e aceitação fossem emanados em estados diferentes; ou que os bens tivessem entrega em Estado diverso dos quais foram emanados os atos de oferta e aceitação) ${ }^{19}$.

Com a criação da Comissão das Nações Unidas para o Direito do Comércio Internacional (UNCITRAL) em 1968, voltou-se a pensar em um texto uniforme que tutelasse a compra e venda internacional de mercadorias de forma mais simples e clara. Assim, já em sua primeira sessão, a UNCITRAL deliberou pela criação de uma nova lei uniforme para reger a matéria (e não revisar as Leis de Haia), a fim de obter a mais ampla aceitação, o que começou a ser maturado a partir de 1969, com a criação de um amplo grupo de trabalho composto de Estados-membros que compreendessem todas as tradições jurídicas, políticas e econômicas então existentes, representados por operadores do Direito dos mais diversos matizes (acadêmicos, advogados, membros de governo, etc). Por outro lado, já em 1978, tal grupo de trabalho decidiu unir os temas discutidos (formação do contrato e obrigações das partes) em um único texto. Tal decisão refletiu-se na estrutura do futuro texto a ser criado (a CISG), que possui uma parte de aceitação obrigatória (parte I), mas permite que seus contratantes possam adotar apenas uma das partes seguintes do texto (Parte II ou Parte III, conforme o artigo $92^{20}$ ), o que denomina a doutrina de adoção piecemeal ou à la carte ${ }^{21}$.

Assim, a CISG é formada por quatro partes: a) Parte I - que especifica seu âmbito de validade e traz suas disposições gerais; b) Parte II - dispondo as normas que regem a formação do contrato de compra e venda internacional de mercadorias; c) Parte III - que

19 TRIPODI, Leandro. A Convenção de Viena de 1980: esboço de sua gênese histórica e estrutura normativa. In: VENOSA, Sílvio de Salvo; GAGLIARDI, Rafael Villar; TERASHIMA, Eduardo Ono (orgs.). A Convenção de Viena sobre Contratos de Compra e Venda Internacional de Mercadorias: desafios e perspectivas. São Paulo: Atlas, 2015, p. 5.

20 ORGANIZAÇÃO DAS NAÇÕES UNIDAS. Convenção de Viena sobre Contratos de Compra e Venda Internacional de Mercadorias. Disponível em: <http://www.planalto.gov.br/ccivil_03/_ato2011-2014/2014/decreto/d8327.htm>. Acesso em: 05 ago. 2016: Artigo 92, (1) Qualquer Estado Contratante pode declarar, no momento da assinatura, ratificação, aceitação, aprovação ou acessão, que não adotará a Parte II ou a Parte III da presente Convenção. (2) Qualquer Estado Contratante que tiver feito a declaração prevista no parágrafo anterior com relação à Parte II ou à Parte III da presente Convenção não se considerará Estado Contratante para os efeitos do parágrafo (1) do artigo 1 da presente Convenção, no que concerne às matérias que sejam regidas pela Parte a que se referir a declaração.

21 Desde sua criação, apenas a Noruega exerceu tal reserva. Vide: TRIPODI, Leandro. A Convenção de Viena de 1980: esboço de sua gênese histórica e estrutura normativa. In: VENOSA, Sílvio de Salvo; GAGLIARDI, Rafael Villar; TERASHIMA, Eduardo Ono (orgs.). A Convenção de Viena sobre Contratos de Compra e Venda Internacional de Mercadorias: desafios e perspectivas. São Paulo: Atlas, 2015, p. 7. 
tutela os direitos e obrigações das partes vendedora e compradora nesses contratos; e, por fim, d) Parte IV - com as disposições gerais típicas de Convenções Internacionais (cláusula de vigência, reservas, escolha do depositário ${ }^{22}$, etc).

Internacionalmente, a CISG entrou em vigor em 01 de janeiro de 1988, contando com 85 (oitenta e cinco) Estados Contratantes de abril de $2017^{23}$, os quais representam mais de $80 \%$ do comércio internacional ${ }^{24}$.

\subsection{Interpretação de seu objeto}

Tradicionalmente, o DIPr serve-se de duas formas de solução de conflitos normativos, quais sejam, as regras indiretas e as regras diretas. As primeiras são indicadoras dos critérios para a resolução do conflito de leis no espaço, todavia, sem apresentar, por si sós, a solução do conflito. Por outro lado, as regras diretas, já dispõem os critérios para as soluções de conflitos, prescindindo de quaisquer normas de determinação da lei aplicável. Dessa forma, pode-se afirmar que a CISG é uma norma direta que contribui para a solução de conflitos de leis no espaço ${ }^{25}$, especificamente quanto aos contratos de compra e venda internacional de mercadorias e, assim, facilitando o desenvolvimento do comércio internacional.

A CISG foi elaborada para reger uniformemente os Contratos de Compra e Venda Internacional de Mercadorias. Todavia, seu texto não define o que seria um contrato internacional de compra e venda de mercadorias. Assim, antes de tudo, é necessário

22 Com previsão nos artigos 76 e 77 da Convenção de Viena de 1969 sobre Direito dos Tratados (no Brasil, recepcionada pelo Decreto $\left.\mathrm{n}^{\circ} 7.030 / 2009\right)$, o depositário é a entidade encarregada de receber todos os documentos autênticos relativos à avença (o texto do tratado celebrado, os instrumentos de ratificação e adesão, bem como as possíveis cartas de denúncia). A figura do depositário foi criada quando do advento de grandes tratados multilaterais no Século XX e, até a $1^{\text {a }}$ Guerra Mundial basicamente, esse encargo recaia sobre um dos Estados pactuantes. Com a criação da OIT por meio do Tratado de Versalhes (1919), surgiu o primeiro exemplo de Organização Internacional depositária, tendo tal prática se enrobustecido com a criação da Organização das Nações Unidas (1945). Contemporaneamente, observa-se, inclusive, a escolha do depositário recaindo sobre funcionários mais graduados das Organizações Internacionais, bem como até a função de depositário sendo partilhada por diversos Estados. Nesse sentido, o texto do art. 89 da CISG indica que seu depositário é o Secretário Geral das Nações Unidas. Vide: REZEK, José Francisco. Direito Internacional Público: curso elementar. 13. ed. aum. e atual. São Paulo: Saraiva, 2011, p. 80-81.

23 UNITED NATIONS COMISSION ON INTERNATIONAL TRADE LAW (UNCITRAL). Status of United Nations Convention on Contracts for the International Sales of Goods (Vienna, 1980). Disponível em: $<$ http://www.uncitral.org/uncitral/en/uncitral_texts/sale_goods/1980CISG_status.html>. Acesso em: 03 fev. 2017.

24 SCHWENZER, Ingeborg. Uniform Sales Law: Brazil Joining the CISG Family. In:

; PEREIRA, Cesar A. Guimarães; TRIPODI, Leandro (coords.). A CISG e o Brasil: Convenção das Nações Unidas para os Contratos de Compra e Venda Internacional de Mercadorias. São Paulo: Martial Pons, 2015, p. 3.

25 TRIPODI, Leandro. A Convenção de Viena de 1980: esboço de sua gênese histórica e estrutura normativa. In: VENOSA, Sílvio de Salvo; GAGLIARDI, Rafael Villar; TERASHIMA, Eduardo Ono (orgs.). A Convenção de Viena sobre Contratos de Compra e Venda Internacional de Mercadorias: desafios e perspectivas. São Paulo: Atlas, 2015, p. 3. 
conceituar o que seria um contrato internacional de comércio para que se possa falar em compra e venda internacional de mercadorias. Conforme Bôaviagem, os contratos internacionais de comércio são aqueles que regulam relações comerciais que se ligam a mais de um sistema jurídico e tem como características:

\begin{abstract}
a transcendência do seu objeto, que pode até mesmo pôr em movimento os Estados, ao estipular mecanismos jurídicos em defesa das suas economias, a posição relativa de poder de seus sujeitos no meio internacional e, do ponto de vista jurídico, a incorporação de disposições tendentes a desconectá-los, de fato, tanto das jurisdições nacionais (por via de arbitragem), com até mesmo dos direitos estatais (pela remissão, expressa ou tácita, aos usos e costumes do comércio internacional ${ }^{26}$.
\end{abstract}

Nesse sentido, Fradera ${ }^{27}$ menciona que dois critérios são comumente utilizados para definir um contrato internacional: o econômico e o jurídico. Do ponto de vista econômico, o qual permite ampla discricionariedade interpretativa judicial, o contrato é considerado internacional quando "coloca em jogo os interesses do comércio internacional ou quando concerne a uma operação ultrapassando o âmbito da economia interna”. Já em sua consideração jurídica, "o contrato é internacional quando apresenta um vínculo com várias ordens jurídicas".

Como uma mescla dos critérios acima dispostos, para a regência da compra e venda internacional de mercadorias como um contrato internacional de comércio, afirma Vieira ${ }^{28}$ que os requisitos de aplicação da CISG estão relacionados: a) às partes e a sua conexão a um Estado contratante; ou b) à transação em si. Assim, portanto, somente em casos expressamente determinados em seu próprio texto ou em caso de lacunas que as regras de DIPr de um dos Estados envolvidos em uma compra e venda internacional de mercadorias poderão ser utilizadas para designar se a CISG é ou não aplicável no caso concreto. Ambas as previsões estão respectivamente dispostas nos pontos 1 ("a" e "b") e 2 do artigo 1 da CISG:

\title{
Artigo 1
}

(1) Esta Convenção aplica-se aos contratos de compra e venda de mercadorias entre partes que tenham seus estabelecimentos em Estados distintos:

26 BÔAVIAGEM, Aurélio Agostinho da. Contratos Internacionais de Comércio: a escolha da lei aplicável no âmbito do Mercosul - dificuldades e reforma. In: CASTRO, Thales (org.). Relações internacionais contemporâneas: teorias e desafios. Curitiba: Íthala, 2014, p. 181.

27 FRADERA, Vera Jacob de. O caráter internacional da CISG. In: VENOSA, Sílvio de Salvo; GAGLIARDI, Rafael Villar; TERASHIMA, Eduardo Ono (orgs.). A Convenção de Viena sobre Contratos de Compra e Venda Internacional de Mercadorias: desafios e perspectivas. São Paulo: Atlas, 2015, p. 205. Ainda menciona que uma maior aceitação jurisprudencial do critério econômico na França, bem como a conjugação dos dois critérios na jurisprudência norte-americana.

28 VIEIRA, Fabio Alonso. O campo de aplicação da Convenção de Viena sobre Compra e Venda Internacional de Mercadorias. In: VENOSA, Sílvio de Salvo; GAGLIARDI, Rafael Villar; TERASHIMA, Eduardo Ono (orgs.). A Convenção de Viena sobre Contratos de Compra e Venda Internacional de Mercadorias: desafios e perspectivas. São Paulo: Atlas, 2015, p. 22-23. 
(a) quando tais Estados forem Estados Contratantes; ou

(b) quando as regras de direito internacional privado levarem à aplicação da lei de um Estado Contratante.

(2) Não será levado em consideração o fato de as partes terem seus estabelecimentos comerciais em Estados distintos, quando tal circunstância não resultar do contrato, das tratativas entre as partes ou de informações por elas prestadas antes ou no momento de conclusão do contrato.

Sobre o supramencionado texto do artigo 1, Nalin e Steiner ${ }^{29}$, afirmam que a CISG estabelece duas regras de aplicação:

Alínea (a) caracterizadora da aplicação direta da CISG, aplicável quando houver um contrato internacional de compra e venda de mercadorias firmado por partes com estabelecimento em Estados contratantes diversos e, alínea (b), pela qual se determina sua aplicação indireta, a ser resolvida pelas regras de Direito Internacional Privado que, uma vez aplicadas, "levarem à aplicação da lei de um Estado Contratantes".

Apesar do mencionado silêncio do texto da CISG, Kuyven e Pignatta afirmam que se pode aduzir da interpretação de seus artigos 30 e 53 que os contratos de compra e venda por ela tutelados são aqueles que fazem "nascer uma obrigação de entrega de mercadorias e de transferência de sua propriedade por meio do pagamento de um preço", sendo a mercadoria "aquilo que é objeto de comércio", sejam bens corpóreos ou incorpóreos ${ }^{30}$, que não estejam expressamente excluídos do âmbito de aplicação da CISG por meio do seu artigo 2:

Artigo 2

Esta Convenção não se aplicará às vendas:

(a) de mercadorias adquiridas para uso pessoal, familiar ou doméstico, salvo se o vendedor, antes ou no momento de conclusão do contrato, não souber, nem devesse saber, que as mercadorias são adquiridas para tal uso;

(b) em hasta pública;

(c) em execução judicial;

(d) de valores mobiliários, títulos de crédito e moeda;

(e) de navios, embarcações, aerobarcos e aeronaves;

(f) de eletricidade.

Ainda quanto ao seu campo de aplicação, o artigo 3 da CISG prevê os casos em que para que a compra e venda de mercadorias seja por ela tutelada, deve-se perquirir por mais do que a simples entrega e transferência do domínio da mercadoria, mas também verificar se o

29 NALIN, Paulo; STEINER, Renata C. Compra e venda internacional de mercadorias: a Convenção das Nações Unidas sobre compra e venda internacional de mercadorias (CISG). Belo Horizonte: Fórum, 2016, p. 109.

30 Há várias discussões jurisprudenciais sobre a aplicabilidade da CISG a contratos próximos à compra e venda, tais como troca, compensação, distribuição, pré-contratos, bem como sobre a discussão do da extensão do conceito de mercadoria no âmbito dos bens incorpóreos. Para tal, vide KUYVEN, Fernando; PIGNATTA, Francisco Augusto. Comentários à Convenção de Viena: compra e venda internacional de mercadorias. São Paulo: Saraiva, 2015, p. 55-60. 
comprador fornece parcela substancial do material necessário para a fabricação ou fornecimento de mão-de-obra:

Artigo 3

(1) Serão considerados contratos de compra e venda os contratos de fornecimento de mercadorias a serem fabricadas ou produzidas, salvo se a parte que as encomendar tiver de fornecer parcela substancial dos materiais necessários à fabricação ou à produção.

(2) Não se aplica esta Convenção a contratos em que a parcela preponderante das obrigações do fornecedor das mercadorias consistir no fornecimento de mão-de-obra ou de outros serviços.

O conceito de parcela substancial (ou essencial, a depender da tradução utilizada substantial part ou part essentielle), é duvidoso na doutrina, cabendo a interpretação referente à qualidade/funcionalidade do material envolvido ou ao valor econômico dos elementos fornecidos. O Advisory Council da CISG, em sua Opinion n. 4 sobre o artigo 3 (1) da CISG, afirmou que o critério francês da essencialidade do bem pode ser afastado pelo histórico legislativo da CISG (as Convenções de Haia de 1964 excluíram de seu texto a palavra essencial), devendo o critério de valor econômico prevalecer não havendo fixação de valores ou percentagem - o que deveria ser feito caso a caso - mas em torno de algo mais do que $50 \%$ do valor envolvido ${ }^{31}$. Tal critério deve também ser verificado no momento da celebração do contrato, afirma Vieira, conforme a visão da doutrina dominante para os casos dos contratos mistos (mercadorias + mão-de-obra) $)^{32}$.

31 CISG Advisory Council Opinion No. 4. Disponível em: <http:/www.cisg.law.pace.edu/cisg/CISG-ACop4.html\#op4ii>. Acesso em: 19 mar. 2017, in verbis: "2.1. The Convention uses a vague term, "substantial part", as one of the key elements in the interpretation of Article 3(1) CISG. There are differences among the authentic texts of the Convention ("substantial part", "parte sustancial", and "part essentielle"), which seem to denote different standards of interpretation" [...] "2.5. The legislative history of the Convention supports the conclusion that the essential criterion was rejected. Both Article 6 of the 1964 Uniform Law on International Sale of Goods (ULIS) and Article 1(7) of the 1964 Uniform Law on Formation (ULF) state that the Uniform Law is excluded if the party who orders the goods provides an essential and substantial part of the materials. The word "essential" was deleted suggesting that the essential criteria was rejected by the drafters of the CISG" [...] "2.6. The "economic value" criterion should prevail in the interpretation of the words "substantial part" in Article 3.1 CISG" [...] "2.8. Legal writers who follow the economic value criterion have generally quantified the term "substantial part" by comparing Article 3(1) CISG (substantial) with Article 3(2) CISG (preponderant): substantial being less than preponderant. In this way, legal writers have used the following percentages to quantify substantial: 15\%, between $40 \%$ and $50 \%$, or more generally $50 \%$. At the same time, other authors, although they have not fixed any numbers in regard to the quantification of the term "substantial" have declared that "preponderant" means "considerably more than 50\% of the price" or "clearly in excess of 50\%". Thus it seems that for the latter authors, the quantification of the term "substantial" is placed above the 50\% figure" [...] "2.9. To consider a fixed percentage might be arbitrary due to the fact that the particularities of each case ought to be taken into account; that the scholars are in disagreement; and that the origin of those figures is not clear. Therefore, it does not seem to be advisable to quantify the word "substantial" a priori in percentages. A case-by-case analysis is preferable and thus it should be determined on the basis of an overall assessment".

32 VIEIRA, Fabio Alonso. O campo de aplicação da Convenção de Viena sobre Compra e Venda Internacional de Mercadorias. In: VENOSA, Sílvio de Salvo; GAGLIARDI, Rafael Villar; TERASHIMA, Eduardo Ono (orgs.). A Convenção de Viena sobre Contratos de Compra e Venda Internacional de Mercadorias: desafios e perspectivas. São Paulo: Atlas, 2015, p. 30. 
Por fim, conforme seus artigos 4 e 5, a CISG não regulamenta a validade dos contratos de compra e venda internacional de mercadorias ou os efeitos que podem produzir sobre a propriedade das mercadorias vendidas, nem tampouco tutela a responsabilidade do vendedor por morte ou lesões corporais produzidas pelas mercadorias a quaisquer pessoas. Portanto, rege apenas a formação do contrato de compra e venda internacional e os direitos e obrigações que surgem do contrato para as partes compradora e vendedora

\subsection{Papel da Autonomia da Vontade em seu texto}

A autonomia da vontade é parte de um contexto descrito por Lôbo como "hegemonia do Estado liberal" e que se demonstrou no Direito contratual como princípio que ressaltava a função individual do contrato, a qual englobava os seguintes princípios: a) autonomia privada (ou autonomia da vontade, ou da liberdade contratual); b) obrigatoriedade (pacta sunt servanda ou intangibilidade); c) relatividade subjetiva (ou eficácia relativa às partes contratantes). Portanto, a abrangência da autonomia da vontade engloba um tríplice aspecto, ou seja, a liberdade que possuem as partes contratantes de escolher o tipo contratual, escolher o outro contratante, bem como escolher o conteúdo do contrato ${ }^{33}$.

Nas relações comerciais internacionais, tal liberdade pode ser vista com muito mais clareza do que em muitos dos contratos regidos pelo Direito estatal interno, tais como os abundantes contratos de consumo, em geral contratos em que tais liberdades se encontram bastante mitigadas, senão tolhidas por um dos contratantes (contratos de adesão).

$\mathrm{Na}$ CISG a autonomia da vontade está presente nas disposições dos artigos 8 e 9, in verbis:

\section{Artigo 8}

(1) Para os fins desta Convenção, as declarações e a conduta de uma parte devem ser interpretadas segundo a intenção desta, desde que a outra parte tenha tomado conhecimento dessa intenção, ou não pudesse ignorá-la.

(2) Não sendo caso de aplicação do parágrafo anterior, as declarações e a conduta de uma parte devem ser interpretadas segundo o sentido que lhes teria dado uma pessoa razoável, com a mesma qualificação e nas mesmas circunstâncias da outra parte.

(3) Para determinar a intenção de uma parte, ou o sentido que teria dado uma pessoa razoável, devem ser consideradas todas as circunstâncias pertinentes ao caso,

33 Conforme Paulo Lôbo, atualmente, houve o reconhecimento da importância de princípios contratuais típicos do Estado social (Welfare State) - função social do contrato, boa-fé objetiva e equivalência material do contrato - os quais, apesar de não eliminares os princípios individuais do contrato, limitaram largamente o seu alcance e conteúdo (Princípios sociais dos contratos. Revista Jus Navigandi, Teresina, ano 18, n. 3750. Disponível em: $<$ http://jus.com.br/artigos/25359>. Acesso em: 28 nov. 2016). Assim, para demonstrar que a vontade das partes contratantes não é mais suprema, mas sim condicionada a dispositivos legais vigentes para a promoção de interesses da sociedade em geral, a doutrina civilista utiliza, amiúde, a expressão "autonomia privada", ao invés de autonomia da vontade. 
especialmente negociações, práticas adotadas pelas partes entre si, usos e costumes e qualquer conduta subsequente das partes.

Artigo 9

(1) As partes se vincularão pelos usos e costumes em que tiverem consentido e pelas práticas que tiverem estabelecido entre si.

(2) Salvo acordo em contrário, presume-se que as partes consideraram tacitamente aplicáveis ao contrato, ou à sua formação, todo e qualquer uso ou costume geralmente reconhecido e regularmente observado no comércio internacional, em contratos de mesmo tipo no mesmo ramo de comércio, de que tinham ou devessem ter conhecimento.

Conforme Kuyven e Pignatta, no artigo 8 os usos e costumes são "utilizados para determinar a intenção das partes". Por outro lado, o artigo 9, "os erigiu com força de vínculo jurídico na formação e na conclusão do contrato, complementando o conteúdo do próprio contrato" 34 . Epistemologicamente, focar-se-á neste trabalho, tão somente, a utilização de usos e costumes como aplicação da autonomia da vontade nos termos do artigo 9 da CISG, ou seja, como critério para o preenchimento de lacunas no contratos internacionais de compra e venda $^{35}$.

Do ponto de vista normativo, o costume consiste em uma prática reiterada e uniforme (inverterata consuetudo), associada com uma força normativa oriunda da consciência da coletividade em torno de sua observância obrigatória (opinio juris) ${ }^{36}$. Por outro lado, do ponto de vista econômico, o costume consiste no abandono de práticas ineficientes em prol de outras mais eficientes na regulação das partes envolvidas ${ }^{37}$.

O artigo 9 da CISG demonstra a vontade dos Estados membros dessa Convenção em se submeter sua vontade legislativamente demonstrada no texto da CISG aos usos e costumes praticados entre os contratantes, em clara indicação da possibilidade da derrogação das regras previstas na CISG (exceto as dos artigos 12 e 96, relativos à necessidade de forma escrita para os contratos de compra e venda internacional de mercadorias ${ }^{38}$ ), o que, para Kuyven e

34 KUYVEN, Fernando; PIGNATTA, Francisco Augusto. Comentários à Convenção de Viena: compra e venda internacional de mercadorias. São Paulo: Saraiva, 2015, p. 138.

35 POTSCH, Bernard. Interpretação da vontade das partes no âmbito da Convenção das Nações Unidas sobre Contratos de Compra e Venda Internacional de Mercadorias. In: MORAES, Carlos Eduardo Guerra de; RIBEIRO, Ricardo Lodi (coords.); TIBURCIO, Carmen (org.). Direito Internacional. Rio de Janeiro: Freitas Bastos, 2015, p. 107.

36 SOMBRA, Thiago Luís. Interpretação da conduta das partes, usos e costumes (arts. $8^{\circ}$ e $9^{\circ}$ ). In: VENOSA, Sílvio de Salvo; GAGLIARDI, Rafael Villar; TERASHIMA, Eduardo Ono (orgs.). A Convenção de Viena sobre Contratos de Compra e Venda Internacional de Mercadorias: desafios e perspectivas. São Paulo: Atlas, 2015, p. 264.

37 MOSER, Luiz Gustavo Meira; TIMM, Luciano Benetti. O recurso aos usos e costumes na CISG: uma análise econômica. In: SCHWENZER, Ingeborg; PEREIRA, Cesar A. Guimarães; TRIPODI, Leandro (coords.). A CISG e o Brasil: Convenção das Nações Unidas para os Contratos de Compra e Venda Internacional de Mercadorias. São Paulo: Martial Pons, 2015, p. 112.

38 CONVENÇÃO DAS NAÇÕES UNIDAS SOBRE COMPRA E VENDA INTERNACIONAL DE

MERCADORIAS: Artigo 12. Não se aplicará qualquer das disposições dos artigos 11 e 29, ou da Parte II desta 
Pignatta $^{39}$, se coaduna perfeitamente com a previsão do artigo 6 da mesma Convenção, in verbis:

\section{Artigo 6}

As partes podem excluir a aplicação desta Convenção, derrogar qualquer de suas disposições ou modificar-lhes os efeitos, observando-se o disposto no Artigo 12.

Dessa forma, os usos e costumes do artigo 9 da CISG têm o condão de vincular e obrigar as partes desde que sejam integrados ao contrato de compra e venda internacional de mercadorias, seja pela relação entre as partes (9.1), seja pela sua utilização no comércio internacional (9.2).

A previsão do artigo 9(1) se divide em duas seções: a primeira dispõe sobre a possibilidade de vinculação das partes às práticas estabelecidas em sua relação comercial e a segunda versa acerca da possibilidade de adoção de usos ser acordada, tal como previsto no artigo 8(3). Assim, há uma consciente integração dos usos, costumes e práticas ao contrato firmado, como verdadeiras partes integrantes do contrato. Entretanto, há que se distinguir "práticas" de "usos e costumes". Pode-se falar em "práticas" quando houver uma relação negocial contínua estabelecida entre as partes contratantes em que houve a adoção de condutas frequentes e que se pode assumir de boa fé que tais condutas serão observadas novamente em casos similares. Há divergência jurisprudencial sobre o que seria frequente (dois contratos - Suíça, três ou quatro contratos - Alemanha; diversos contratos durante um ano e alguns meses - França), mas é certo que já tem que haver relação comercial entre os contratantes. Observe-se que a apreciação da existência ou não dos elementos constitutivos de uma prática comercial deve-se dar com a análise das circunstâncias do caso concreto ${ }^{40}$. Por outro lado, quanto à adoção de "usos e costumes" acordados entre as partes e já existentes no

Convenção, que permita a celebração, alteração ou rescisão do contrato de compra e venda, ou a proposta, aceitação ou qualquer manifestação de intenção, por outra forma que não a escrita, quando uma das partes tiver seu estabelecimento comercial em Estado Contratante que tenha feito a declaração prevista no artigo 96 desta Convenção. As partes não poderão derrogar nem modificar o efeito do presente artigo. [...] Artigo 96. O Estado Contratante cuja legislação exigir que os contratos de compra e venda sejam concluídos ou provados por escrito poderá, a qualquer momento, fazer a declaração prevista no artigo 12, no sentido de que, caso qualquer das partes tenha seu estabelecimento comercial nesse Estado, não se aplicarão as disposições dos artigos 11 e 29, ou da Parte II da presente Convenção, que permitirem a conclusão, modificação ou resolução do contrato de compra e venda, ou a proposta, aceitação ou qualquer outra manifestação de intenção por qualquer forma que não a escrita.. Vide: BRASIL. Decreto ${ }^{\circ} 8.327$, de 16 de outubro de 2014. Disponível em: $<$ http://www.planalto.gov.br/ccivil_03/_Ato2011-2014/2014/Decreto/D8327.htm>. Acesso em: 05 out. 2016. 39 KUYVEN, Fernando; PIGNATTA, Francisco Augusto. Comentários à Convenção de Viena: compra e venda internacional de mercadorias. São Paulo: Saraiva, 2015, p. 139.

40 POTSCH, Bernard. Interpretação da vontade das partes no âmbito da Convenção das Nações Unidas sobre Contratos de Compra e Venda Internacional de Mercadorias. In: MORAES, Carlos Eduardo Guerra de; RIBEIRO, Ricardo Lodi (coords.); TIBURCIO, Carmen (org.). Direito Internacional. Rio de Janeiro: Freitas Bastos, 2015, p. 114-116. 
comércio internacional, estes se destinam a tutelar para os casos de vínculos inéditos entre contratantes que ainda não celebraram contratos de compra e venda internacional de mercadorias anteriormente ${ }^{41}$. Ademais, o artigo 9(1) deve ser interpretado de forma a considerar tal acordo inclusive em sua forma implícita e, no que diz respeito à amplitude dos usos acordados, as partes podem utilizar quaisquer usos e costumes (internacionais, domésticos, locais ou até mesmo de outro setor de comércio) ${ }^{42}$.

Por outro lado, no caso do artigo 9(2) os usos e costumes do comércio internacional só não serão aplicáveis ao contrato se as partes expressamente os excluírem, ou seja, é a vontade das partes que determina sua aplicação. Assim, prevê-se a complementação da vontade das partes por meio dos usos e costumes regularmente conhecidos por contratantes no mesmo ramo de comércio (pode ser local ou regional, não sendo necessário que seja um costume ou uso universalmente reconhecido ou observado, mas que não abrange usos aplicados somente ao comércio doméstico de um único Contratante), mas para tal as partes devem conhecê-los anteriormente, de forma real ou ficta e, para isso, as partes devem praticar suas atividades em local onde o uso ou costume seja observado. Ademais, tal uso ou costume deve preexistir ao contrato, não sendo imponível em caso de advento posterior à celebração do contrato CISG, salvo se as partes vierem a modificá-10 ${ }^{43}$. Por fim, ressalte-se que tais usos e costumes devem ter interpretação autônoma em relação a algum direito nacional ${ }^{44}$.

Como já visto, a uniformização das regras do comércio internacional gera eficiência econômica por possibilitar a redução dos custos de transação no mercado ${ }^{45} \mathrm{e}$, por isso, pode-se dizer que a CISG atende a uma racionalidade econômica internacional ${ }^{46}$. Nesse contexto, em

41 KUYVEN, Fernando; PIGNATTA, Francisco Augusto. Comentários à Convenção de Viena: compra e venda internacional de mercadorias. São Paulo: Saraiva, 2015, p. 141.

42 POTSCH, Bernard. Interpretação da vontade das partes no âmbito da Convenção das Nações Unidas sobre Contratos de Compra e Venda Internacional de Mercadorias. In: MORAES, Carlos Eduardo Guerra de; RIBEIRO, Ricardo Lodi (coords.); TIBURCIO, Carmen (org.). Direito Internacional. Rio de Janeiro: Freitas Bastos, 2015, p. 114-115.

43 POTSCH, Bernard. Interpretação da vontade das partes no âmbito da Convenção das Nações Unidas sobre Contratos de Compra e Venda Internacional de Mercadorias. In: MORAES, Carlos Eduardo Guerra de; RIBEIRO, Ricardo Lodi (coords.); TIBURCIO, Carmen (org.). Direito Internacional. Rio de Janeiro: Freitas Bastos, 2015, p. 117-119.

44 KUYVEN, Fernando; PIGNATTA, Francisco Augusto. Comentários à Convenção de Viena: compra e venda internacional de mercadorias. São Paulo: Saraiva, 2015, p. 141.

45 Uma vez que há naturalmente uma incerteza constitucional das bases jurídicas do comércio international, em razão de sua ligação com mais de um sistema jurídico, o que gera custos (dificuldades) por razões diversas: incerteza da lei aplicável, o difícil acesso à doutrina sobre leis aplicáveis, dificuldade de aconselhamento jurídico sobre o direito estrangeiro, etc, tal como indicado por BASEDOW, Jürgen. Lex Mercatoria and the Private International Law of Contracts in Economic Perspective. In: BASEDOW, Jürgen; KONO, Toshiyuki. An Economic Analysis of Private International Law. Tübingen: Mohr Siebeck, 2006, p. 69.

46 TIMM, Luciano Benetti; MOSER, Luiz Gustavo Meira. A análise econômica do Direito Contratual na Convenção de Viena sobre Venda Internacional de Mercadorias (CISG). In: VENOSA, Sílvio de Salvo; GAGLIARDI, Rafael Villar; TERASHIMA, Eduardo Ono (orgs.). A Convenção de Viena sobre Contratos de 
caso de omissão contratual, dentre as formas utilizadas pela CISG para a diminuição dos custos de transação dos contratos de compra e venda internacional de mercadorias está a consagração convencional da autonomia da vontade dos contratantes como critério para solução de possíveis controvérsias oriundas desses contratos, com a utilização de usos e costumes ou práticas internacionais a que tiverem consentido (artigo 9). Tal disposição corrobora com a existência no âmbito do comércio internacional de "contratos sem lei" ou "quase auto regulatórios", ou seja, aqueles não se referem a um ordenamento nacional em caso de controvérsia haja vista seu minucioso detalhamento ${ }^{47}$.

A seguir, encarar-se-á a questão da autonomia da vontade contratual como critério para escolha da norma aplicável às obrigações no ordenamento brasileiro, em uma visão histórica, e as consequências da recepção da CISG em sua extensão no Direito pátrio.

\section{AUTONOMIA DA VONTADE CONTRATUAL NO ORDENAMENTO JURÍDICO BRASILEIRO}

Neste capítulo serão tecidos comentários sobre a presença e evolução do alcance do princípio da autonomia da vontade ${ }^{48}$ no ordenamento jurídico brasileiro, considerando-se sua previsão no tocante aos contratos internacionais, antes e depois da recepção da CISG no ordenamento brasileiro.

\subsection{Sob a égide do Código Civil de 1916}

Até o advento do primeiro Código Civil brasileiro, no Brasil as relações jurídicas privadas eram tuteladas pelas ordenações portuguesas (relações civis) ou pelo Código Comercial - Lei no 556/1850 - e Regulamento nº 737/1850 (relações mercantis). As primeiras previam como critério para a escolha da norma aplicável aos contratos o princípio locus regit actum, ou seja, a aplicação da lei do local em que as obrigações se formassem para sua

Compra e Venda Internacional de Mercadorias: desafios e perspectivas. São Paulo: Atlas, 2015, p. 662.

47 GARCEZ, José Maria Rossani. Lei de regência nos contratos de compra e venda internacional de mercadorias celebrados no Brasil. In: SCHWENZER, Ingeborg; PEREIRA, Cesar A. Guimarães; TRIPODI, Leandro (coords.). A CISG e o Brasil: Convenção das Nações Unidas para os Contratos de Compra e Venda Internacional de Mercadorias. São Paulo: Martial Pons, 2015, p. 568.

48 Ressalte-se que, em razão de se enfocar tão-somente nos aspectos individuais dos contratos, mas sem desconsiderar a importância dos princípios sociais incidentes sobre a matéria contratual (vide nota de rodapé 33), continuar-se-á a falar em "autonomia da vontade" e não em "autonomia privada" na abordagem da tutela jurídica dos contratos internacionais no presente trabalho. 
regência ${ }^{49}$. Por outro lado, nas relações mercantis, o mencionado Regulamento previa em seus $\operatorname{artigos} 4^{\circ}$ e $5^{\circ}$ a adoção das normas brasileiras para a tutela de contratos celebrados em Estado estrangeiro, mas cujo cumprimento se daria no Brasil ou para as dívidas contraídas entre brasileiros em solo estrangeiro, in verbis:

Art. $4^{\circ}$. Os contratos commerciaes, ajustados em paiz estrangeiro mas exequiveis no Imperio, serão regulados e julgados pela legislação commercial do Brazil.

Art. $5^{\circ}$. Presumem-se contrahidas (conforme a legislação do Brazil as dividas entre Brazileiros em paiz estrangeiro).

Assim, durante o século XIX e início do século XX, para a solução de possível controvérsia contratual houve a predominância do da utilização do princípio da aplicação da lei do local da celebração dos contratos, com a mitigação para relações mercantis das disposições acima colacionadas e, legislativamente, não se previra a possibilidade de aplicação do princípio da autonomia da vontade para a solução de controvérsias contratuais.

Entretanto, parte relevante da doutrina já defendia a aplicação da autonomia da vontade nas relações contratuais controversas, mesmo que em graus distintos de aceitação. Sobre o desenvolvimento histórico do princípio da autonomia da vontade, Eduardo Espínola afirmou existirem três períodos: combate, exagero e reação. O primeiro, combate, remonta à criação da noção de autonomia da vontade por Dumoulin e aqueles que o criticavam; o segundo, exagero, ao tempo em que se estendeu o princípio das leis supletivas até englobar as leis imperativas, tal como na visão de Savigny e Hauss; já a última fase seria dividida em duas correntes, a ítalo-germano-francesa teoria das limitações (Anzilotti, Von Bar, Pillet) - que dividia o que era regido imperativamente pela lei e o que era supletivo, e que poderia ser tutelado pela autonomia da vontade - e a teoria da eliminação de Dreyfus, que afirmava estar a vontade submetida ao domínio da lei, seja ela imperativa ou supletiva (portanto, negava a possibilidade de uma autonomia da vontade contratual $)^{50}$.

Dessa forma, e mencionada a evolução da visão sobre a autonomia contratual, no bojo do movimento republicano brasileiro, maturou-se a ideia de um código civil pátrio, que organizasse as relações particulares não comerciais tal como o Code Civil francês de 1804 e o Bürgerliches Gesetzbuch (BGB) de 1900.

Assim, foi criado Código Civil brasileiro por meio da Lei $n^{\circ} 3.071 / 1916$, com um texto cuja extensão condizia com a hercúlea tarefa de codificar as relações particulares no Brasil

49 ARAUJO, Nadia de. Contratos Internacionais: Autonomia da Vontade, Mercosul e Convenções Internacionais. 4 ed. Rio de Janeiro: Renovar, 2009, p. 97.

50 VILLELA, Álvaro da Costa Machado. O Direito Internacional Privado no Código Civil Brasileiro. Coimbra: Imprensa da Universidade, 1921, p. 368-377. 
(1.807 artigos), e que conjugadamente trazia em seu bojo uma introdução formada por 21 artigos. Tal introdução tutelava, entre diversas matérias, as vigências territorial, temporal e espacial da lei e, dentre estas últimas, dispunha em seu art. 13 sobre o conflito de leis no espaço no que tange às obrigações, in verbis:

Art. 13. Regulará, salvo estipulação em contrário, quanto á substância e aos efeitos das obrigações, a lei do lugar, onde forem contraídas.

Parágrafo único. Mas sempre se regerão pela lei brasileira:

I. Os contratos ajustados em países estrangeiros, quando exeqüíveis no Brasil.

II. As obrigações contraídas entre brasileiros em país estrangeiro.

III. Os atos relativos a imóveis situados no Brasil.

IV. Os atos relativos ao regime hipotecário brasileiro ${ }^{51}$.

A intepretação do dispositivo acima pela doutrina era diversa, exemplificativamente, com Clóvis Beviláqua ${ }^{52}$ e Eduardo Espínola $^{53}$ favoráveis à autonomia das partes, sendo o primeiro um crítico das exceções enumeradas nos incisos do próprio artigo e o segundo as admitindo por serem de caráter imperativo, uma vez que tais normas não poderiam ser afastadas por vontade das partes; já Carvalho $\operatorname{Santos}^{54}$ afirmava que a autonomia só se expressava com a expressa estipulação em contrário e, na sua ausência aplicável a norma geral do art. 13.

Com o advento da Lei de Introdução de 1942 (Decreto-Lei no 4.657/1942, então mais conhecido como Lei de Introdução ao Código Civil ou LICC) ${ }^{55}$ houve a revogação das disposições da mencionada Introdução ao Código Civil e foi então prevista a nova tutela das obrigações:

Art. 9 Para qualificar e reger as obrigações, aplicar-se-á a lei do país em que se constituírem.

$\S 1$ Destinando-se a obrigação a ser executada no Brasil e dependendo de forma essencial, será esta observada, admitidas as peculiaridades da lei estrangeira quanto aos requisitos extrínsecos do ato.

$\S 2$ A obrigação resultante do contrato reputa-se constituída no lugar em que residir o proponente.

Como se observa, foi suprimida nesse dispositivo a expressão "salvo estipulação em contrário" constante no art. 13 da Introdução ao Código Civil de 1916. Isso fez surgir novas

51 BRASIL. Lei $n^{\circ}$ 3.071, de $1^{\circ}$ de janeiro de 1916. Disponível em: $<$ http://www.planalto.gov.br/ccivil_03/leis/L3071.htm>. Acesso em: 04 jun. 2017.

52 BEVILÁQUA, Clóvis. Código Civil Anotado. v.1. 12 ed. Rio de Janeiro: Livraria Francisco Alves, 1959, p. 110.

53 ESPÍNOLA, Eduardo. Anotações ao Código Civil Brasileiro. v.1. 2 ed. Rio de Janeiro: Casa Graphica, 1929, p. 262-264.

54 SANTOS, J. M. Carvalho. Código Civil Brasileiro Anotado. v.1. 4 ed. Rio de Janeiro: Livraria Freitas Bastos, 1950, p. 161-162.

55 BRASIL. Decreto-Lei $n^{o}$ 4.657, de 4 de setembro de 1942. Disponível em: $<$ http://www.planalto.gov.br/ccivil_03/decreto-lei/Del4657.htm>. Acesso em: 04 jun. 2017. 
posições sobre a polêmica previsão da autonomia da vontade no ordenamento jurídico brasileiro, agora à luz do texto caput do art. $9^{\circ}$ da LICC (que, por força da Lei ${ }^{\circ}$ 12.376/2010, atualmente é denominada Lei de Introdução às normas do Direito Brasileiro ou LINDB).

Sobre tal dispositivo, Valladão ${ }^{56}$ afirma que mesmo com a modificação do texto em relação ao art. 13 da antiga Introdução ao Código Civil de 1916 ainda se pode falar na presença da autonomia da vontade em razão da disposição do parágrafo $2^{\circ}$ do $\operatorname{art.} 9^{\circ}$, uma vez que a:

[...] fórmula "presume-se", "reputa-se", cobre sempre o princípio da autonomia da vontade, abrindo a tradicional ressalva "salvo estipulação em contrário", ou "em falta de vontade expressa ou tácita”. Havendo tal escolha, expressa ou tácita, não predomina a lei da residência do proponente, substituída pela eleita pelas partes.

À luz desse dispositivo, Diniz ${ }^{57}$ afirma que no campo dos contratos não há guarida à autonomia da vontade como elemento de conexão ${ }^{58}$, pois “o art. $9^{\circ}$ da Lei de Introdução é cogente, não podendo as partes alterá-lo”. Assim, restaria às partes apenas uma liberdade contratual no campo das normas supletivas, nunca podendo prevalecer tal autonomia a normas de ordem pública ou normas imperativas (cogentes).

Por sua vez, Dolinger defende não existir qualquer óbice à autonomia da vontade com o advento do art. $9^{\circ}$ da Lei de Introdução, pois à luz do: “princípio da continuidade das leis, pelo qual não se considera revogada norma anterior se não expressamente revogada pela posterior e nada consta na LICC de 1942 que tenha modificado o contido na ICC de 1916"59. Tal pensamento parece se basear no fato de o Decreto-Lei $n^{\circ} 4.707 / 1942$, que dispõe sobre a vigência da Lei de Introdução ao Código Civil (Decreto-Lei $n^{\circ}$ 4.657/1942) ter disposto que “O decreto-lei no 4.657, de 4 de setembro de 1942 (Lei de Introdução ao Código Civil Brasileiro) entrará em vigor no dia 24 de outubro do corrente ano, revogadas as disposições em contrário". Assim, sem, portanto, ter havido revogação expressa do conteúdo da

56 VALlADÃO, Haroldo. Direito Internacional Privado em base histórica e comparativa, positiva e doutrinária, especialmente dos Estados Americanos: parte especial, conflitos de leis civis, v. II. 2 ed., rev. e atual. Rio de Janeiro: Freitas Bastos, 1977, p. 186.

57 DINIZ, Maria Helena. Lei de Introdução ao Código Civil Brasileiro Interpretada. 11 ed. São Paulo: Saraiva, 2005, p. 286-287.

58 Conforme VALLADÃO, Haroldo. Direito Internacional Privado em base histórica e comparativa, positiva e doutrinária, especialmente dos Estados Americanos: introdução e parte geral, v. I. Rio de Janeiro: Freitas Bastos, 1968, p. 266: "elementos de conexão são as diretrizes, as chaves, as cabeças-de-ponte para a solução dos conflitos de leis" e MAZZUOLI, Valério de Oliveira. Curso de Direito Internacional Privado. 3 ed. Rio de Janeiro: Forense, 2018, p. 133: “são os 'elementos de localização' do direito aplicável, isto é, aqueles que a legislação interna de cada Estado toma em consideração e entende como relevantes para a indicação do direito substancial aplicável”.

59 DOLINGER, Jacob. Direito Internacional Privado: Contratos e Obrigações no Direito Internacional Privado. Rio de Janeiro: Renovar, 2007, p. 458. 
Introdução ao Código Civil de 1916, teria havido a permanência do princípio da autonomia da vontade no contratos dentro do direito brasileiro.

Sobre a tutela da LINDB, Araujo afirma que existe, historicamente, na doutrina brasileira três correntes sobre a presença ou não da autonomia da vontade no campo dos contratos:

A primeira, daqueles enfaticamente contrários à autonomia da vontade; a segunda, daqueles a favor, desde que limitada às regras supletivas, excluindo-se, portanto, a possibilidade de sua aplicação ao contrato como um todo; e finalmente a terceira, daqueles favoráveis à teoria de forma mais ampla. ${ }^{60}$

Em suma, à luz do Código Civil brasileiro de 1916 e sua introdução do mesmo ano, bem como do Decreto-Lei $n^{\circ} 4.657 / 1942$ (atual LINDB), a discussão sobre a aceitação da autonomia da vontade nunca cessou, com relevantes doutrinadores a favor e contra sua aplicação, apenas se tornou mais acirrada em face da redação do art. $9^{\circ}$ deste último diploma. Entretanto, com o advento da Lei $n^{\circ}$ 9.307/1996, a questão se expandiu com a introdução da autonomia da vontade no âmbito da arbitragem, como se verá a seguir.

\subsection{O advento da Lei ${ }^{\circ}$ 9.307/1996}

A Lei $\mathrm{n}^{\mathrm{o}} 9.307 / 1996^{61}$ (Lei de Arbitragem) foi criada para tutelar o instituto da arbitragem no ordenamento jurídico brasileiro, a fim de, conforme Araujo, "mudar a atitude dos brasileiros na maneira de resolver seus litígios de ordem patrimonial, pois não é mais possível ficar esperando que a Justiça estatal solucione todas as pendências privadas" ${ }^{62}$. Nesse afã, seu art. $2^{\circ}$ instituiu possibilidade de utilização da autonomia da vontade nos seguintes termos:

\footnotetext{
Art. $2^{\circ} \mathrm{A}$ arbitragem poderá ser de direito ou de eqüidade, a critério das partes.

$\S 1^{\circ}$ Poderão as partes escolher, livremente, as regras de direito que serão aplicadas na arbitragem, desde que não haja violação aos bons costumes e à ordem pública. $\S 2^{\circ}$ Poderão, também, as partes convencionar que a arbitragem se realize com base nos princípios gerais de direito, nos usos e costumes e nas regras internacionais de comércio.

$\S 3^{\circ} \mathrm{A}$ arbitragem que envolva a administração pública será sempre de direito e respeitará o princípio da publicidade.
}

60 ARAUJO, Nadia de. Contratos Internacionais: Autonomia da Vontade, Mercosul e Convenções Internacionais. 4 ed. Rio de Janeiro: Renovar, 2009, p. 119.

61 BRASIL. Lei $n^{\circ} 9.307$, de 23 de setembro de 1996. Disponível em: $<$ http://www.planalto.gov.br/ccivil_03/leis/L9307.htm>. Acesso em: 04 jun. 2017.

62 ARAUJO, Nadia de. Contratos Internacionais: Autonomia da Vontade, Mercosul e Convenções Internacionais. 4 ed. Rio de Janeiro: Renovar, 2009, p. 120. 
Como se pode observar, os parágrafos $1^{\circ}$ e $2^{\circ}$ do art. $2^{\circ}$ mencionado preveem a liberdade de as partes envolvidas em um procedimento arbitral escolherem livremente, mas não somente, as regras jurídicas aplicáveis na arbitragem, como também a utilização de princípios gerais de direito, usos, costumes e regras internacionais de comércio, desde que tais normas não firam os bons costumes e a ordem pública brasileira.

Há que se observar cizânias doutrinárias acerca da expressão "regras de direito que serão aplicadas na arbitragem" constante no $\S 1^{\circ}$ do retromencionado artigo, em dois pontos: a) alcance da expressão - com autores afirmando que tal expressão denota apenas as regras que regem o procedimento arbitral e não o mérito do litígio, enquanto outros consideram que tal expressão abrange tanto as regras de procedimento quanto as que serão aplicadas ao litígio em si; b) origem das regras utilizadas - as regras seriam somente as nacionais ou tal expressão abrangeria regras nacionais e não nacionais? Para essa última questão, razoavelmente se pode considerar que o parágrafo $3^{\circ}$ do art. $2^{\circ}$ resolve essa questão quando menciona que "as partes convencionar que a arbitragem se realize com base nos princípios gerais de direito, nos usos e costumes e nas regras internacionais de comércio" ${ }^{63}$. Como exemplo de regras internacionais de comércio utilizáveis na arbitragem, podem-se mencionar os Princípios para os Contratos Comerciais Internacionais criados pelo UNIDROIT.

No que tange ao alcance e limites da autonomia da vontade na Lei $n^{\circ}$ 9.307/1996, observa-se que, a despeito da primeira cizânia doutrinária citada, expressamente houve somente limites à autonomia da vontade em caso de "violação aos bons costumes e à ordem pública", sem o que se pode crer que a autonomia da vontade envolve não somente a eleição das normas procedimentais serem adotadas pelos árbitros, mas também do direito material que será aplicado para solucionar a o litígio, servindo como uma garantia às partes estrangeiras que desejem contratar no Brasil, uma vez que as partes já sabem de antemão qual será a lei a ser aplicada para solucionar possível demanda em face de descumprimento contratual. Assim, pode-se falar em não aplicação do art. $9^{\circ}$ da LINDB em caso de previsão contratual de submissão de uma possível disputa a uma arbitragem, pois, "optando as partes pela via arbitral, automaticamente elas estarão aptas a ignorar o determinado pela LICC/42

63 A UNIDROIT promoveu a tradução de seus Princípios Relativos aos Contratos Comerciais Internacionais pela autoria de Lauro Gama Jr. Disponível $<$ http://www.unidroit.org/english/principles/contracts/principles2010/translations/blackletter2010portuguese.pdf $>$. Acesso em: 07 jun. 2017. 
(sic), uma vez que o artigo $2^{\circ}$ da Lei de Arbitragem concede ampla autonomia da vontade às partes" $"$.

De outra banda, há que se questionar se a autonomia da vontade prevista na Lei de Arbitragem abrange a também a arbitragem interna ou apenas a arbitragem internacional? Como a Lei $\mathrm{n}^{\mathrm{o}}$ 9.307/1996 adotou um sistema monista (que regula arbitragens interna e internacionais), à luz do parágrafo $2^{\circ}$ do art. $2^{\circ}$ podem-se aplicar normas internacionais para a solução de uma arbitragem nacional (mesmo que isso seja até improvável) e só se pode falar em afastamento dessa norma quando a utilização das normas internacionais para solução de arbitragem nacional for considerada uma tentativa de fraude à lei nacional ${ }^{65}$.

Entretanto, quando não houver escolha pelas partes da lei aplicável em caso de arbitragem, como se deve proceder? Atualmente, as instituições de arbitragem têm considerado que, na ausência de escolha das partes, o árbitro é livre para eleger a lei que considerar mais apropriada para o caso concreto, seja ela nacional ou internacional (convenções ou normas de Soft Law, tais como Leis Modelo ou Guidelines), com base no princípio da proximidade, ou seja, casuisticamente se definirá a norma aplicável. Tal liberdade dos árbitros se pode presumir porque se as partes detêm o poder delegar aos árbitros o poder de decidir o litígio, também se pode considerar que detenham o poder para dirimir a questão da lei aplicável. E, se por acaso não desejam delegar aos árbitros tal poder, têm a capacidade de escolher a lei nacional, ou regra de direito, a ser aplicada no momento da contratação ${ }^{66}$.

Por fim, há que se mencionar que os defensores da arbitragem como preferencial forma de solução de contratos (principalmente os internacionais) afirmam que uma de suas grandes vantagens é que os árbitros, por serem desvinculados da estrutura estatal, geram menos incerteza jurídica, ínsita ao juízo judiciário estatal e, ademais, seria consistiria no locus mais propício à utilização da lex mercatoria, pois, como mencionou Strenger, "dada a sua crescente desvinculação, seja das leis impositivas nacionais, seja das jurisdições estatais" ${ }^{67}$. Assim,

64 SOMENSI, Mariana Furlanetto. As inovações introduzidas pela Lei n ${ }^{0}$ 9.307/1996 relativamente à escolha da lei do contrato internacional. In: FRADERA, Véra Jacob de; MOSER, Luiz Gustavo Meira. A Compra e Venda Internacional de Mercadorias: estudos sobre a Convenção de Viena de 1980. São Paulo: Atlas, 2011, p. 90-91. Observe-se que a sigla LICC/42 utilizada é, após a edição da Lei n 12.376/2010, a atual LINDB.

65 SOMENSI, Mariana Furlanetto. As inovações introduzidas pela Lei $\mathrm{n}^{\circ}$ 9.307/1996 relativamente à escolha da lei do contrato internacional. In: FRADERA, Véra Jacob de; MOSER, Luiz Gustavo Meira. A Compra e Venda Internacional de Mercadorias: estudos sobre a Convenção de Viena de 1980. São Paulo: Atlas, 2011, p. 93-94. 66 Ibidem, p. 96.

67 STRENGER, Irineu. Direito do Comércio Internacional e Lex Mercatoria. São Paulo: LTr, 1996, p. 71. Na mesma obra, o autor conceitua a Lex Mercatória como "um conjunto de procedimentos que possibilita adequadas soluções para as expectativas do comércio internacional, sem conexões necessárias com os sistemas nacionais e de forma juridicamente eficaz" (p. 78). 
poder-se-ia distinguir a arbitragem da jurisdição estatal, após o advento da Lei no 9.307/1996, por consistir num locus em que a lex mercatoria (e, portanto, a autonomia da vontade) é utilizável para solução controvérsias sobre contratos.

Assim, a seguir, serão tecidas algumas considerações sobre a autonomia da vontade contratual no ordenamento brasileiro após a adesão à CISG.

\section{3 À luz da CISG.}

Introdutoriamente e, antes de tratar da autonomia da vontade contratual no ordenamento jurídico brasileiro após a vinculação à CISG, convém destacar que o Brasil não assinou a CISG e seu conteúdo só foi introduzido no Direito brasileiro após a aprovação pelo Congresso Nacional em 18 de outubro de 2012, por meio do Decreto Legislativo $n^{\circ}$ 538/2012, o que possibilitou a adesão do Brasil a seu texto em 04 de março de 2013. Dessa forma, em razão da disposição do artigo 99 (2) da $\mathrm{CISG}^{68}$, a mesma começou a vincular juridicamente o Brasil no dia $1^{\circ}$ de abril de 2014. Consequentemente, a fim de conferir-lhe status de norma interna, houve a recepção de seu texto em 16 de outubro de 2014 com a publicação do Decreto $\mathrm{n}^{\circ}$ 8.327, o qual aperfeiçoou a condição da CISG como norma vinculante no âmbito interno e internacional brasileiro.

Pelo já demonstrado no tópico 2.3 supra pode-se falar em autonomia da vontade no texto da CISG no bojo de seu artigo 8 e, especialmente, do artigo 9, o qual novamente se coloca in verbis:

\section{Artigo 9}

(1) As partes se vincularão pelos usos e costumes em que tiverem consentido e pelas práticas que tiverem estabelecido entre si.

(2) Salvo acordo em contrário, presume-se que as partes consideraram tacitamente aplicáveis ao contrato, ou à sua formação, todo e qualquer uso ou costume geralmente reconhecido e regularmente observado no comércio internacional, em contratos de mesmo tipo no mesmo ramo de comércio, de que tinham ou devessem ter conhecimento.

Tal disposição reforça a ideia de utilização ampla da autonomia da vontade no Direito brasileiro nas hipóteses de aplicação previstas no artigo 1 da CISG nos contratos de compra e venda internacional de mercadorias em que as partes tenham estabelecimentos em Estados distintos (quando tais Estados forem contratantes da CISG ou quando as regras de DIPr levarem à aplicação da lei de um Estado contratante).

68 BRASIL. Decreto $n^{o} 8.327$, de 16 de outubro de 2014. Disponível em: <http://www.planalto.gov.br/ccivil_03/ _Ato2011-2014/2014/Decreto/D8327.htm>. Acesso em: 05 out. 2016. 
Anteriormente à plena vigência da CISG no ordenamento brasileiro ( $1^{\circ}$ de abril de 2014), sua aplicação só seria possível em duas hipóteses: a) pelo Judiciário no caso em que nossas regras de colisionais indicassem a aplicação da legislação vigente de um Estado contratante; ou b) no âmbito de controvérsias contratuais em que se previsse a solução por meio de arbitragem, haja vista as disposições da Lei n 9.307/1996. Consequentemente, a aplicação da autonomia da vontade prevista nos termos do artigo 9 da CISG também era restrita às mesmas hipóteses até a vigência dessa convenção.

Nesse sentido da ampliação da autonomia da vontade no ordenamento brasileiro, prevê o artigo 113 do Código Civil brasileiro de 2002 (Lei no 10.406/2002) que "os negócios jurídicos devem ser interpretados conforme a boa-fé e os usos do lugar de sua celebração". Fradera $^{69}$ menciona sua proposição na V Jornada de Direito Civil de um enunciado interpretativo (número 409) de tal dispositivo, sob inspiração do artigo 9 da CISG (mesmo antes de sua adesão pelo Brasil), com a seguinte redação: “os negócios jurídicos devem ser interpretados não só conforme a boa fé e os usos e costumes do lugar de sua celebração, mas também de acordo com as práticas habitualmente adotadas pelas partes”.

Assim, após a vigência da CISG pode-se falar em uma autonomia da vontade ampla no campo dos contratos de compra e venda internacional de comércio, tal como previsto no texto de seu artigo 9 e não somente nos casos restritos de aplicação reflexa ou no âmbito de possível procedimento arbitral (internacional ou interno, diga-se) para solução de controvérsias nos contratos previstos no artigo 1 da CISG.

\section{CONCLUSÃO}

A autonomia da vontade em matéria contratual é questão historicamente polêmica e extremamente relevante para a prática do comércio internacional, uma vez que o instrumento contratual é a base das trocas no âmbito do comércio, garantindo-lhe segurança e aceitação amplas. Da mesma forma, a definição das normas utilizáveis para a interpretação do próprio contrato em caso de desavença se demonstra imprescindível e também controversa, uma vez que os Estados tendem a manter tal definição no âmbito de sua legislação interna, como no

69 FRADERA, Vera Jacob de. A interpretação dos negócios jurídicos empreendidos no Brasil: o alargamento das hipóteses previstas no artigo 113 do Código Civil brasileiro mediante inspiração do artigo $9^{\circ}$ da CISG. In: SCHWENZER, Ingeborg; PEREIRA, Cesar A. Guimarães; TRIPODI, Leandro (coords.). A CISG e o Brasil: Convenção das Nações Unidas para os Contratos de Compra e Venda Internacional de Mercadorias. São Paulo: Martial Pons, 2015, p. 573. 
caso do Brasil e sua vigente Lei de Introdução, que estipulou, em seu art. $9^{\circ}$, como regra geral a regência das obrigações pela norma do local da celebração dos pactos.

Entretanto, no âmbito do comércio (e, principalmente do comércio internacional) a utilização histórica dos usos e práticas comerciais como base para a solução de controvérsias é um fator que agrega segurança às relações comerciais e isso tende a torna-las menos onerosas, influenciando positivamente toda a cadeia de consumo a qual tutelam. Nesse sentido, a adesão do Brasil ao texto da Convenção das Nações Unidas sobre Contratos de Compra e Venda Internacional de Mercadorias de 1980 em $1^{\circ}$ de abril de 2014 proporcionou uma ampliação no ordenamento brasileiro da possibilidade de utilização de normas uniformes próprias do comércio internacional na interpretação dos contratos por meio de seus artigos 8 e 9, integrando o Brasil de forma mais efetiva ao comércio internacional com redução da incerteza jurídica contratual e, consequentemente, menor custo para os envolvidos em uma compra e venda internacional.

Dessa forma, pode-se chegar à conclusão que houve uma ampliação da autonomia da vontade contratual no ordenamento jurídico brasileiro após a recepção da CISG pelo Brasil, haja vista que tal autonomia era somente permitida de forma ampla no âmbito do procedimento arbitral (salvo em caso de ofensa à ordem pública e aos bons costumes) e se, em caso de contratos de compra e venda internacional de mercadorias nos termos do artigo 1 da CISG, as normas de DIPr brasileiras indicassem a aplicação da lei de um Estado contratante da CISG. Assim, após a recepção da CISG pelo ordenamento brasileiro, pode-se falar em utilização ampla da autonomia da vontade para todos os casos de contratos de compra e venda internacional de mercadorias nos termos da CISG.

\section{REFERÊNCIAS}

ARAUJO, Nadia de. Contratos Internacionais: Autonomia da Vontade, Mercosul e Convenções Internacionais. 4 ed. Rio de Janeiro: Renovar, 2009.

ARAUJO, Nadia de; SPITZ, Lidia; TEIXEIRA, Bruno Barreto de Azevedo. Diálogo das fontes: interações entre a lei doméstica e a CISG. In: VENOSA, Sílvio de Salvo; GAGLIARDI, Rafael Villar; TERASHIMA, Eduardo Ono (orgs.). A Convenção de Viena sobre Contratos de Compra e Venda Internacional de Mercadorias: desafios e perspectivas. São Paulo: Atlas, 2015, p. 589-604.

BASEDOW, Jürgen. Lex Mercatoria and the Private International Law of Contracts in Economic Perspective. In: BASEDOW, Jürgen; KONO, Toshiyuki. An Economic Analysis of Private International Law. Tübingen: Mohr Siebeck, 2006, p. 57-71. 
BEVILÁQUA, Clóvis. Código Civil Anotado. v.1. 12 ed. Rio de Janeiro: Livraria Francisco Alves, 1959.

BÔAVIAGEM, Aurélio Agostinho da. Contratos Internacionais de Comércio: a escolha da lei aplicável no âmbito do Mercosul - dificuldades e reforma. In: CASTRO, Thales (org.).

Relações internacionais contemporâneas: teorias e desafios. Curitiba: Íthala, 2014, p.181194.

BORGES, José Souto Maior. Curso de Direito Comunitário. 2. ed. São Paulo: Saraiva, 2009.

BRASIL. Lei $n^{o} 3.071$, de $1^{\circ}$ de janeiro de 1916. Disponível em: <http://www.planalto.gov.br/ ccivil_03/leis/L3071.htm>. Acesso em: 04 jun. 2017.

BRASIL. Decreto-Lei $n^{\circ} 4.657$, de 4 de setembro de 1942. Disponível em:

$<$ http://www.planalto.gov.br/ccivil_03/decreto-lei/Del4657.htm>. Acesso em: 04 jun. 2017.

BRASIL. Lei $n^{\circ}$ 9.307, de 23 de setembro de 1996. Disponível em:

$<$ http://www.planalto.gov.br/ccivil_03/leis/L9307.htm>. Acesso em: 04 jun. 2017.

BRASIL. Decreto $n^{\circ} 8.327$, de 16 de outubro de 2014. Disponível em:

$<$ http://www.planalto.gov.br/ccivil_03/_Ato2011-2014/2014/Decreto/D8327.htm>. Acesso em: 05 out. 2016.

CASADO FILHO, Napoleão. Breve introdução sobre a CISG e sua aplicabilidade no Brasil. In: VENOSA, Sílvio de Salvo; GAGLIARDI, Rafael Villar; TERASHIMA, Eduardo Ono (orgs.). A Convenção de Viena sobre Contratos de Compra e Venda Internacional de Mercadorias: desafios e perspectivas. São Paulo: Atlas, 2015, p. 11-20.

CISG Advisory Council Opinion No. 4. Disponível em:

$<$ http://www.cisg.law.pace.edu/cisg/CISG-AC-op4.html\#op4ii>. Acesso em: 19 mar. 2017.

DINIZ, Maria Helena. Lei de Introdução ao Código Civil Brasileiro Interpretada. 11 ed. São Paulo: Saraiva, 2005.

DOLINGER, Jacob. Direito Internacional Privado: Contratos e Obrigações no Direito Internacional Privado. Rio de Janeiro: Renovar, 2007.

ESPÍNOLA, Eduardo. Anotações ao Código Civil Brasileiro. v.1. 2 ed. Rio de Janeiro: Casa Graphica, 1929.

FRADERA, Vera Jacob de. A interpretação dos negócios jurídicos empreendidos no Brasil: o alargamento das hipóteses previstas no artigo 113 do Código Civil brasileiro mediante inspiração do artigo $9^{\circ}$ da CISG. In: SCHWENZER, Ingeborg; PEREIRA, Cesar A. Guimarães; TRIPODI, Leandro (coords.). A CISG e o Brasil: Convenção das Nações Unidas para os Contratos de Compra e Venda Internacional de Mercadorias. São Paulo: Martial Pons, 2015, p. 569-574. 
FRADERA, Vera Jacob de. O caráter internacional da CISG. In: VENOSA, Sílvio de Salvo; GAGLIARDI, Rafael Villar; TERASHIMA, Eduardo Ono (orgs.). A Convenção de Viena sobre Contratos de Compra e Venda Internacional de Mercadorias: desafios e perspectivas. São Paulo: Atlas, 2015, p. 203-216.

FRIEDMAN, Thomas L. The World is Flat: a brief history of the twenty-first century. $3^{\text {rd }}$ ed., further updated and expanded. New York: Picador/Farrar, Straus and Giroux, 2007.

GARCEZ, José Maria Rossani. Lei de regência nos contratos de compra e venda internacional de mercadorias celebrados no Brasil. In: SCHWENZER, Ingeborg; PEREIRA, Cesar A. Guimarães; TRIPODI, Leandro (coords.). A CISG e o Brasil: Convenção das Nações Unidas para os Contratos de Compra e Venda Internacional de Mercadorias. São Paulo: Martial Pons, 2015, p. 555-568.

GICO JR, Ivo T. Metodologia e Epistemologia da Análise Econômica do Direito. Economic Analysis of Law Review, v. 1, n. 1, p. 22, jan-jun, 2010. Disponível em:

$<$ https://portalrevistas.ucb.br/index.php/EALR/article/view/1460>. Acesso em: 01 mar. 2017.

JAYME, Erik. Identité culturelle et intégration: le droit international privé postmoderne. Recueil des Cours, The Hague, v. 251, p. 9-267, 1996.

KUYVEN, Fernando; PIGNATTA, Francisco Augusto. Comentários à Convenção de Viena: compra e venda internacional de mercadorias. São Paulo: Saraiva, 2015.

LÔBO, Paulo. Princípios sociais dos contratos. Revista Jus Navigandi, Teresina, ano 18, $\mathrm{n}$. 3750. Disponível em: <http://jus.com.br/artigos/25359>. Acesso em: 28 nov. 2016.

MAZZUOLI, Valério de Oliveira. Curso de Direito Internacional Privado. 3 ed. Rio de Janeiro: Forense, 2018.

MOSER, Luiz Gustavo Meira; TIMM, Luciano Benetti. O recurso aos usos e costumes na CISG: uma análise econômica. In: SCHWENZER, Ingeborg; PEREIRA, Cesar A. Guimarães; TRIPODI, Leandro (coords.). A CISG e o Brasil: Convenção das Nações Unidas para os Contratos de Compra e Venda Internacional de Mercadorias. São Paulo: Martial Pons, 2015, p. $108-117$.

NALIN, Paulo; STEINER, Renata C. Compra e venda internacional de mercadorias: a Convenção das Nações Unidas sobre compra e venda internacional de mercadorias (CISG). Belo Horizonte: Fórum, 2016.

OCAMPO, Raúl Granillo. Direito Internacional Público da Integração. Rio de Janeiro: Elsevier, 2009.

ORGANIZAÇÃO DAS NAÇÕES UNIDAS. Convenção de Viena sobre Contratos de Compra e Venda Internacional de Mercadorias. Disponível em: $<$ http://www.planalto.gov.br/ ccivil_03/_ato2011-2014/2014/decreto/d8327.htm>. Acesso em: 05 ago. 2016.

PIGNATTA, Francisco Augusto. A uniformização das regras do contrato de compra e venda internacional de mercadorias: suas vantagens, seus desafios. In: SCHWENZER, Ingeborg; 
PEREIRA, Cesar A. Guimarães; TRIPODI, Leandro (coords.). A CISG e o Brasil: Convenção das Nações Unidas para os Contratos de Compra e Venda Internacional de Mercadorias. São Paulo: Martial Pons, 2015, p. 38-55.

POTSCH, Bernard. Interpretação da vontade das partes no âmbito da Convenção das Nações Unidas sobre Contratos de Compra e Venda Internacional de Mercadorias. In: MORAES, Carlos Eduardo Guerra de; RIBEIRO, Ricardo Lodi (coords.); TIBURCIO, Carmen (org.). Direito Internacional. Rio de Janeiro: Freitas Bastos, 2015, p. 99-120.

REZEK, José Francisco. Direito Internacional Público: curso elementar. 13. ed. aum. e atual. São Paulo: Saraiva, 2011.

ROWE, Michael. Convenção das Nações Unidas sobre lei do comércio internacional. In: BAPTISTA, Luiz Olavo; MAZZUOLI, Valerio de Oliveira (orgs.). Direito Internacional: Direito do Comércio Internacional, v. 5. São Paulo: RT, 2012, p. 875-884.

SANTOS, J. M. Carvalho. Código Civil Brasileiro Anotado. v.1. 4 ed. Rio de Janeiro: Livraria Freitas Bastos, 1950.

SCHWENZER, Ingeborg. Uniform Sales Law: Brazil Joining the CISG Family. In: PEREIRA, Cesar A. Guimarães; TRIPODI, Leandro (coords.). A CISG e o Brasil: Convenção das Nações Unidas para os Contratos de Compra e Venda Internacional de Mercadorias. São Paulo: Martial Pons, 2015, p. 21-37.

SHINN, Terry (Desencantamento da modernidade e da pós-modernidade: diferenciação, fragmentação e a matriz de entrelaçamento. Sci. stud., São Paulo, v. 6, n. 1, p. 43-81, Mar. 2008. Disponível em: <http://www.scielo.br/scielo.php?script=sci_arttext\&pid=S1678$31662008000100003 \& \operatorname{lng}=\mathrm{en} \& \mathrm{nrm}=\mathrm{iso}>$. Acesso em: 18 jul. 2019.

SOARES, Guido Fernando Silva. Curso de Direito Internacional Público. v. 1. 2. ed. São Paulo: Saraiva, 2004.

SOMBRA, Thiago Luís. Interpretação da conduta das partes, usos e costumes (arts. $8^{\circ}$ e $9^{\circ}$ ). In: VENOSA, Sílvio de Salvo; GAGLIARDI, Rafael Villar; TERASHIMA, Eduardo Ono (orgs.). A Convenção de Viena sobre Contratos de Compra e Venda Internacional de Mercadorias: desafios e perspectivas. São Paulo: Atlas, 2015, p. 258-267.

SOMENSI, Mariana Furlanetto. As inovações introduzidas pela Lei n ${ }^{\circ}$ 9.307/1996 relativamente à escolha da lei do contrato internacional. In: FRADERA, Véra Jacob de; MOSER, Luiz Gustavo Meira. A Compra e Venda Internacional de Mercadorias: estudos sobre a Convenção de Viena de 1980. São Paulo: Atlas, 2011, p. 88-107.

SOUZA JR., Lauro Gama. A Convenção de Viena sobre compra e venda internacional de mercadorias. In: BAPTISTA, Luiz Olavo; MAZZUOLI, Valerio de Oliveira (orgs.). Direito Internacional: Direito do Comércio Internacional, v. 5. São Paulo: RT, 2012, p. 719-736.

STRENGER, Irineu. Direito do Comércio Internacional e Lex Mercatoria. São Paulo: LTr, 1996. 
TIMM, Luciano Benetti; MOSER, Luiz Gustavo Meira. A análise econômica do Direito Contratual na Convenção de Viena sobre Venda Internacional de Mercadorias (CISG). In: VENOSA, Sílvio de Salvo; GAGLIARDI, Rafael Villar; TERASHIMA, Eduardo Ono (orgs.). A Convenção de Viena sobre Contratos de Compra e Venda Internacional de Mercadorias: desafios e perspectivas. São Paulo: Atlas, 2015, p. 651-671.

TRIPODI, Leandro. A Convenção de Viena de 1980: esboço de sua gênese histórica e estrutura normativa. In: VENOSA, Sílvio de Salvo; GAGLIARDI, Rafael Villar; TERASHIMA, Eduardo Ono (orgs.). A Convenção de Viena sobre Contratos de Compra e Venda Internacional de Mercadorias: desafios e perspectivas. São Paulo: Atlas, 2015, p. 1-10.

UNITED NATIONS COMISSION ON INTERNATIONAL TRADE LAW (UNCITRAL). Status of United Nations Convention on Contracts for the International Sales of Goods (Vienna, 1980). Disponível em:

$<$ http://www.uncitral.org/uncitral/en/uncitral_texts/sale_goods/1980CISG_status.html>. Acesso em: 03 fev. 2017.

VALLADÃO, Haroldo. Direito Internacional Privado em base histórica e comparativa, positiva e doutrinária, especialmente dos Estados Americanos: introdução e parte geral, v. I. Rio de Janeiro: Freitas Bastos, 1968.

VALLADÃO, Haroldo. Direito Internacional Privado em base histórica e comparativa, positiva e doutrinária, especialmente dos Estados Americanos: parte especial, conflitos de leis civis, v. II. 2 ed., rev. e atual. Rio de Janeiro: Freitas Bastos, 1977.

VIEIRA, Fabio Alonso. O campo de aplicação da Convenção de Viena sobre Compra e Venda Internacional de Mercadorias. In: VENOSA, Sílvio de Salvo; GAGLIARDI, Rafael Villar; TERASHIMA, Eduardo Ono (orgs.). A Convenção de Viena sobre Contratos de Compra e Venda Internacional de Mercadorias: desafios e perspectivas. São Paulo: Atlas, 2015, p. 21-34.

VILLELA, Álvaro da Costa Machado. O Direito Internacional Privado no Código Civil Brasileiro. Coimbra: Imprensa da Universidade, 1921.

\section{DADOS DA PUBLICAÇÃO}

Categoria: artigo submetido ao double-blind review.

Recebido em: 06/07/2018.

Aceito em: 22/07/2019. 


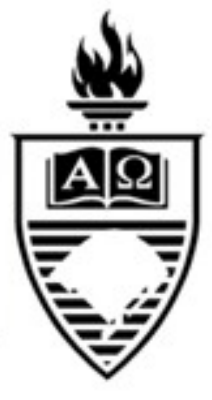

